Working Paper/Document de travail 2015-13

\title{
Euro Area Government Bonds-Integration and Fragmentation During the Sovereign Debt Crisis
}

by Michael Ehrmann and Marcel Fratzscher 
Bank of Canada Working Paper 2015-13

April 2015

\title{
Euro Area Government Bonds-Integration and Fragmentation During the Sovereign Debt Crisis
}

\author{
by \\ Michael Ehrmann ${ }^{1}$ and Marcel Fratzscher ${ }^{2}$ \\ 1International Economic Analysis Department \\ Bank of Canada \\ Ottawa, Ontario, Canada K1A OG9 \\ mehrmann@bankofcanada.ca \\ 2DIW Berlin \\ 10117 Berlin, Germany \\ and \\ Humboldt University Berlin and CEPR \\ mfratzscher@diw.de
}

Bank of Canada working papers are theoretical or empirical works-in-progress on subjects in economics and finance. The views expressed in this paper are those of the authors.

No responsibility for them should be attributed to the Bank of Canada. 


\section{Acknowledgements}

We would like to thank the participants at the Canadian Economic Association 2014 annual conference, in particular our discussant Chiara Scotti, as well as seminar participants at the Bank of Canada for helpful comments, Michelle Bissessarsingh and Kasia Bankowska for their help with the data, and Daniel Schneider for excellent research assistance. 


\begin{abstract}
The paper analyzes the integration of euro area sovereign bond markets during the European sovereign debt crisis. It tests for contagion (i.e., an intensification in the transmission of shocks across countries), fragmentation (a reduction in spillovers) and flight-to-quality patterns, exploiting the heteroskedasticity of intraday changes in bond yields for identification. The paper finds that euro area government bond markets were well integrated prior to the crisis, but saw a substantial fragmentation from 2010 onward. Flight to quality was present at the height of the crisis, but has largely dissipated after the European Central Bank's (ECB's) announcement of its Outright Monetary Transactions (OMT) program in 2012. At the same time, Italy and Spain became more interdependent after the OMT announcement, providing our only evidence of contagion. While this suggests that countries have been effectively ring-fenced, and Italy and Spain benefited from the joint reduction in yields following the OMT announcement, the high current degree of fragmentation poses difficult challenges for policy-makers, since it leads to an unequal transmission of the ECB's monetary policy to the various countries.
\end{abstract}

JEL classification: F3, E5, G15

Bank classification: Asset pricing; Financial markets; Interest rates; International financial markets

\title{
Résumé
}

Dans la présente étude, les auteurs examinent le degré d'intégration des marchés des obligations d'État de la zone euro durant la crise de la dette souveraine en Europe. Ils recherchent des indices de contagion (intensification de la propagation des chocs entre les pays), de fragmentation (réduction des effets de débordement) et de fuite vers les titres de qualité en s'appuyant sur l'hétéroscédasticité qui caractérise les variations intrajournalières des rendements obligataires pour repérer les chocs. Ils constatent que les marchés des obligations d'État de la zone euro sont fortement intégrés avant la crise, mais connaissent une importante fragmentation à partir de 2010. On remarque, au plus fort de la crise, une ruée vers les titres de qualité, qui diminue sensiblement après l'annonce du lancement du programme d'opérations monétaires sur titres (OMT) de la Banque centrale européenne (BCE) en 2012. Par ailleurs, le lien d'interdépendance entre l'Italie et l'Espagne se resserre à la suite de cette annonce, ce qui représente le seul cas avéré de contagion dans l'étude. Un tel résultat porte à croire que les pays de la zone euro ont été bien protégés les uns des autres. D'autre part, l'Italie et l'Espagne ont tiré avantage de la diminution conjointe des rendements dans le sillage de la création du programme d'OMT. Cependant, le niveau élevé de fragmentation à l'heure actuelle met les décideurs publics à rude épreuve, en ce qu'il induit une transmission inégale de la politique monétaire de la BCE dans les différents pays.

Classification JEL : F3, E5, G15

Classification de la Banque : Évaluation des actifs; Marchés financiers; Taux d'intérêt; Marchés financiers internationaux 


\section{Non-Technical Summary}

As the euro area is starting to emerge from its deep crisis, a debate is taking place about the lessons from the crisis and about the effectiveness of the various policy responses. A key motivation for many of the policy responses was to prevent a spillover of the crisis across countries and markets. With hindsight, it is therefore important to assess the transmission of shocks across sovereign debt markets of the euro area, whether this transmission intensified during the crisis, and how it was influenced by policy. To address these questions, the paper analyzes the integration of euro area sovereign bond yields and its evolution over time. It tests for contagion (i.e., an intensification in the transmission of shocks across countries), fragmentation (a reduction in spillovers) and flight-to-quality patterns.

The paper shows that the euro area has experienced substantial fragmentation across national sovereign bond markets since the beginning of the European sovereign debt crisis in 2010. Prior to 2010, European bond markets were highly integrated, with yields across all euro area countries co-moving closely with those of German government bonds. Since the start of the European crisis in 2010, this co-movement has become considerably weaker, suggesting a general fragmentation of markets. In addition, we observe more cases of a flight to quality during the crisis, whereby shocks to yields in several stressed countries moved French and German yields in the opposite direction, a phenomenon that largely disappears after the European Central Bank’s (ECB’s) announcement of its Outright Monetary Transactions (OMT) program.

Importantly, however, there is generally no evidence of contagion; i.e., we typically do not find a strengthening in the transmission of sovereign risk shocks across euro area countries between 2010 and 2012. On the contrary, fragmentation means that the transmission of shocks had generally become weaker during that period. The only exception to this is the case of Italy and Spain. Both were part of the euro area core before the crisis, but started decoupling from the core euro area countries. This decoupling intensified after the announcement of the OMT program in the summer of 2012, while the bidirectional spillovers among these two countries increased, constituting our only case of a contagious pattern. This finding is consistent with Italy and Spain being the main targets of the OMT program.

What do these findings imply for policy? On the one hand, the pattern of disintegration identified in this paper may be partly desirable, since it prevented a more systemic crisis in the euro area through stronger cross-country linkages. Indeed, the findings of the paper reject the contagion hypothesis, which dominated the policy discussions for much of the crisis. On the other hand, the high degree of fragmentation also poses difficult challenges for policy-makers, since it leads to an unequal transmission of the ECB's monetary policy to the various countries. It is therefore important to see whether and to what degree market integration will rise again once the crisis abates. 


\section{Introduction}

As the euro area is starting to emerge from its deep crisis, a debate is taking place about the lessons from the crisis and about the effectiveness of policy responses. A key motivation for many of the crisis policies was to prevent a spillover of the crisis across countries and markets. Containing the crisis was an important consideration when the European Union (EU) and the International Monetary Fund (IMF) granted Greece a large rescue program in May 2010, and the decision of the European Central Bank (ECB) to purchase the government debt of troubled euro area countries under its Securities Markets Program (SMP) aimed to avoid the transmission of shocks and a panic across sovereign debt markets. These attempts culminated in the ECB's Outright Monetary Transactions (OMT) program, announced between July and September 2012, with the aim of preventing a speculative attack in sovereign debt markets of the euro area.

With hindsight, it is therefore important to assess the transmission of shocks across sovereign debt markets of the euro area, whether this transmission intensified during the crisis, and how it was influenced by policy. The difficulty is that while the European crisis may have started in Greece, it also affected many other countries such as Ireland, Portugal, Cyprus and Spain-all of which received rescue programs. Did the crisis in Greece trigger financial stress in other euro area countries? And to what extent were problems in the large euro area countries, such as Spain and Italy, contagious for other countries?

If we want to address these questions, it is important at the outset to define the terminology. There is a large body of literature on contagion in financial markets, ${ }^{1}$ which usually defines contagion as a strengthening in the transmission of shocks across countries or across markets. While we will use this very definition of contagion in this paper, too, the objective of euro area policy-makers may not have been to merely prevent an increase in the shock transmission, but to ring-fence a crisis country. In other words, policy-makers might have been trying to reduce or even completely eliminate the transmission of shocks across sovereign debt markets during the crisis.

This suggests a second relevant dimension of our analysis, which is the issue of integration and fragmentation of financial markets. A remarkable feature of the European crisis was that it triggered a massive repatriation of capital to investors' home countries. Many banks and other investors reduced lending to other countries in order to meet liquidity needs and increase investments at home. This triggered a massive increase in the home bias of investors, in particular when it comes to sovereign debt. In 2008, more than $70 \%$ of the government debt by Portugal, Greece and Ireland was owned by foreign investors. This ratio declined with the onset of the European crisis, in many cases to below 30\%. While this development reduced cross-country integration, it raised the interdependence between banks and their domestic governments, with the ratio of domestic government debt relative to bank assets doubling or tripling in crisis and noncrisis countries alike. ${ }^{2}$

Figure 1 shows the evolution of 10-year government bond yields among eight euro area countries since 2008. Initially, spreads across countries were low and there was a high degree of co-movement between all euro area countries. This high degree of integration persisted even after the collapse of Lehman Brothers in September 2008 and well into

\footnotetext{
${ }^{1}$ Dungey and Martin (2007) provide a good review, with seminal work by Bae, Karolyi and Stulz (2003) and Forbes and Rigobon (2002), and more recent work by Bekaert et al. (2014) on contagion during the global financial crisis.

${ }^{2}$ See, e.g., the ECB Monthly Bulletin, August 2012.
} 
2009. Greek yields started rising at the end of 2009, soon followed by those of Portugal and Ireland, and then by those of Italy and Spain in late 2010. In contrast, spreads among the core countries (Germany, France and the Netherlands) remained narrow. There are some individual periods—such as around May 2010, August 2011 and April 2012—when there appears to be a negative co-movement between yields in the periphery and in the core. Yields among all countries then appear to narrow since the summer of 2012, after the ECB's announcement of its OMT program.

Figure 1 here

The figure underlines that there are periods with disintegration or fragmentation, and others where integration remained high or increased, with a large degree of heterogeneity across countries. The objective of the paper is to test the direction of causality in euro area sovereign bond markets during the European crisis. Was there contagion, i.e. an intensification in the spillovers from one country to other euro area countries, and if so, to which? Did we see flight to quality, i.e. instances where a shock that raises yields in a stressed country would lower yields in the core? And to what extent did countries decouple from the developments in other countries? The main challenge for such an analysis is the identification of shocks to individual bond markets. To achieve identification, we employ a methodology that exploits the heteroskedasticity of changes in bond yields, using high-frequency, five-minute data for the above-mentioned eight euro area bond markets.

We employ two alternative ways to identify regimes: one that uses the statistical properties of our data, i.e. the change in intraday volatility in yield changes, and a second based on a narrative approach for days when the media focus was on one particular country. Rather than imposing assumptions about the direction of contemporaneous spillovers across euro area markets, our methodology allows us to test for them. We distinguish three different subperiods to test our hypotheses: the pre-European crisis period till late 2009, the European crisis period from early 2010 to spring 2012, and the post-OMT from October 2012 to the end of 2013.

Three major findings emerge from the analysis. The first one is the strong evidence of a widespread fragmentation of euro area bond markets during the European crisis. Due to the status of the German government as the benchmark bond among the euro area countries, all other bond yields co-moved very strongly with German yields before the crisis: $80-90 \%$ of a shock to German yields was transmitted to other markets. The transmission of these shocks to the stressed countries decreased markedly during the 2010-12 period, to around 30-70\%, and became statistically insignificant or even smaller at $0-30 \%$ in the post-OMT period.

A second major result is the evidence of a flight-to-quality pattern. Being restricted to a quantitatively small phenomenon originating from Greece in the pre-crisis sample, at the height of the crisis, flight to quality was observed in response to shocks to Italian, Portuguese and Irish yields. Especially, changes in Italian yields led to large opposite movements of French and German yields. By the end of our sample, most of these flightto-quality patterns have disappeared. They remain statistically significant for Italy, but are quantitatively smaller than previously.

The third key finding of this paper is the general absence of contagion among the stressed countries, with one notable exception: Italy and Spain, which before 2010 were fully part of the core euro area, started behaving as an asset class by themselves, with little 
spillovers to the other stressed countries but a massive increase in bidirectional spillovers after the announcement of the ECB's OMT program in the summer of 2012. This is intriguing but also intuitive, since the main reason for the OMT program was the concern about these two countries' ability to remain solvent and withstand a speculative attack on their sovereign debt markets (whereas the other stressed countries all had IMF-EU programs and were thus not eligible, since they did not fulfill the OMT conditionality).

While it is difficult to causally attribute the changing patterns of euro area government bond market spillovers to the ECB's announcement of its OMT program, our findings are consistent with the set-up of the program. Under OMT, we see an increased degree of integration within the core and within Italy and Spain, whereas the fragmentation across these groups increased even further. This might have been the intended outcome-Italy and Spain saw their yields decline in tandem, and largely unrelated to the developments in the other markets. Still, the high degree of fragmentation also poses difficult challenges for policy-makers currently and in the future, since it leads to an unequal transmission of the ECB's monetary policy to the various countries. It is therefore important to see whether and to what degree market integration will rise again once the crisis abates.

Our paper relates to various strands of literature. First, methodologically, we rely on the seminal work by Sentana and Fiorentini (2001) and Rigobon (2003), who developed the approach of identification through heteroskedasticity (IH). In his original application, Rigobon (2003) studied the interdependence of government bond yields during financial crises just like we do here. The IH approach has subsequently been applied in different contexts. For instance, Rigobon and Sack (2003a,b) study the link between monetary policy and equity markets, and Andersen et al. (2007) and Ehrmann et al. (2011b) use the methodology to identify spillovers across asset prices in the United States and Europe. In contrast to the current paper, these studies focus on the regular interdependence patterns, rather than on changes in the transmission. ${ }^{3}$

Second, there is a large literature on the behavior of euro area government bond yields. The early years of monetary union have been characterized by a strong convergence in yields, both in terms of their levels and their responsiveness to new information (Ehrmann et al. 2011a). With hindsight and using data following the global financial crisis, it has become apparent that, prior to 2008, government bond markets were barely pricing credit default risk, and accordingly were largely unresponsive to a country's fundamentals (Beirne and Fratzscher 2013; D’Agostino and Ehrmann 2014). This has changed in particular since the onset of the European sovereign debt crisis. Countries with poor fundamentals saw their yields increasing dramatically, a pattern that has been identified as "wake-up call” contagion (Arghyrou and Alexandros 2012; Giordano et al. 2013).

Beyond this type of contagion, whereby a crisis initially restricted to one country provides new information that may prompt investors to reassess the vulnerability of other countries (Goldstein 1998), there has been very little evidence of contagion. While correlations among government bond yields have increased substantially, both Claeys

\footnotetext{
${ }^{3}$ More generally, there have been various analyses of international spillovers, though the focus in this literature has mostly been on equity markets. For instance, the work by Hamao et al. (1990), King et al. (1994) and Lin et al. (1994), based on reduced-form GARCH models, detects some spillovers from the U.S. to the Japanese and U.K. equity markets, both for returns and in particular for conditional volatility. Bekaert et al. (2009) document return spillovers across 23 countries, with no evidence of an upward trend in return correlations overall but some upward trend for the European stock markets. Diebold and Yilmaz (2009) develop a spillover index based on VAR models, and show that the evolution of return and volatility spillovers across 19 stock markets is strikingly different.
} 
and Vašíček (2014) and Caporin et al. (2013) suggest that this is generally not due to contagion but can be explained by the presence of larger shocks. Caporin et al. (2013) even find that spillover coefficients have gone down (whereas they should have gone up in the presence of contagion). This finding is consistent with the idea of market fragmentation, which has been found for the unsecured euro area money market (Garcia de Andoain et al. 2014) as well as for government bond markets (Battistini et al. 2014).

A third strand of the literature is concerned with the effect of central bank policies on government bond yields. Rogers et al. (2014) study the unconventional monetary policies of several central banks (including those of the ECB), and find these to be effective in easing financial conditions when policy rates are at the effective lower bound. With many of its policies, the ECB tried to affect liquidity conditions in financial markets, given that these are crucial for a smooth market functioning in times of market stress (Beber et al. 2009). As a matter of fact, the ECB's long-term refinancing operations have been found to have lowered credit risk and eased liquidity strains (Pelizzon et al. 2014). Its purchases of government bonds in the context of the SMP have been shown to lower government bond yields (Ghysels et al. 2014), and to substantially reduce the market perceptions of joint default risk across euro area governments (Lucas et al. 2014). Finally, there is evidence that the ECB's OMT has led to a reduction in the yields of Italian and Spanish government bonds (Altavilla et al. 2014).

The paper is organized as follows. The second section discusses the methodology and data used in the analysis. The third section presents the empirical findings and reports results from robustness tests. A discussion of the conclusions and implications follows in section 4.

\section{Empirical Methodology and Data}

In this section, we outline our estimation methodology and the data we use for our empirical analysis.

\subsection{Identification and model estimation}

The starting point of our analysis is a simple structural model, in which bond markets are determined simultaneously in the following way:

$$
A y_{t}=\vartheta+\Pi(L) y_{t-1}+\Psi z_{t}+\mu_{t} \text {, }
$$

with $y_{t}$ a vector of the endogenous variables, i.e. the changes in long-term bond yields of eight euro area countries. $\Pi(L)$ indicates the lagged effects of the endogenous variables, and $\Psi$ the effects of a set of exogenous variables $z_{t}$. This vector of exogenous variables in the basic specification includes day-of-the-week and hour-of-the-day dummies, but can be extended to include other relevant exogenous shocks.

The off-diagonal elements of matrix $A$ are of main interest to us, since they indicate the contemporaneous spillovers across euro area bond markets. However, equation (1) cannot be estimated. Instead, we estimate the reduced-form model: 


$$
\begin{aligned}
& y_{t}=A^{-1} \vartheta+A^{-1} \Pi(L) y_{t-1}+A^{-1} \Psi z_{t}+A^{-1} \mu_{t} \\
& y_{t}=C_{0}+B_{0}(L) y_{t-1}+B_{1} z_{t}+\varepsilon_{t},
\end{aligned}
$$

which allows us to obtain the coefficients in $C_{0}, B_{0}, B_{1}$ and the variance-covariance matrix of the reduced-form residuals $\varepsilon_{t}$. One possibility to identify the elements of $A$ is to impose zero restrictions on some of the matrices; alternatively, sign restrictions also have often been applied for identification. However, financial market prices are jointly determined, which makes zero restrictions (whereby the bond yields of one country do not simultaneously affect those of another country) implausible. Sign restrictions, in turn, typically lead to a large admissible parameter space. Also, we do not want to impose sign restrictions, since this is precisely what we want to estimate from the data: in the presence of flight-to-safety effects, spillovers have the opposite direction than under a normal transmission that moves yields in the same direction. In other words, we want to be as agnostic as possible about the sign and size of the different elements of the system.

We therefore adopt an IH approach, which exploits the fact that financial variables tend to be heteroskedastic. The methodology has been developed by Sentana and Fiorentini (2001) and Rigobon (2003); details about the derivation are provided there. The idea of $\mathrm{IH}$ is that the existence of heteroskedastic regimes solves the identification problem. For this to be possible, however, two conditions need to hold. One is that the structural shocks must be uncorrelated, which is a common assumption in the vector autoregression (VAR) literature. A second condition is that the matrix $A$ is stable across the heteroskedasticity regimes. While this might sound restrictive, it is important to note that the same assumption is applied when estimating ARCH-type models. Each additional heteroskedastic regime has a different variance-covariance matrix of the shocks. Estimation of the system under different regimes therefore adds more equations than unknowns, so that the identification problem is solved when at least two regimes can be identified. $^{4}$

One complication is that model (2) is identified by the heteroskedasticity in the data only up to a rotation of the matrix $A$, requiring the imposition of some additional restrictions, which can be either exclusion or sign restrictions. However, each of these and other overidentifying restrictions can be tested for their validity. Our preferred restriction is to assume that a rise in the yields of Germany raises yields in each of the other countries, and a reduction in German yields also lowers yields elsewhere. In other words, we assume that shocks to German yields do not trigger flight-to-quality flows into other countries (whereas we allow for the possibility that there are such flight-to-quality flows toward Germany). In terms of the matrix $A$, this assumption implies negative coefficients in the first column, i.e. $\alpha_{21}<0, \alpha_{31}<0, \ldots, \alpha_{81}<0$. The empirical results show that these restrictions are actually not binding; however, they help us in the estimation process. ${ }^{5}$

\footnotetext{
${ }^{4}$ In a system with $N$ endogenous variables, the matrix $A$ has $N(N-1)$ terms (since the elements on the diagonal are normalized to one), and the variance-covariance matrix of the structural form residuals has $N$ terms (since the covariances are assumed to be zero)—which accounts for a total of $N^{2}$ unknowns. On the other hand, the variance-covariance matrix of the reduced-form residuals provides $N(N+1) / 2$ equations. This leaves $N(N-1) / 2$ unidentified parameters. Under the assumptions specified above, we can estimate a reduced-form covariance matrix for each heteroskedasticity regime, providing $N(N+1) / 2$ additional equations, but only $N$ additional unknowns. Therefore, the existence of two regimes will already be sufficient for exact identification of the model: the second regime adds $N(N+1) / 2-N=N(N-1) / 2$ free parameters, equal to the unidentified $N(N-1) / 2$ parameters.

${ }^{5}$ The reason is that the sign restrictions limit the space in which parameters have to be searched to minimize the moment restrictions. This influences the speed of convergence, but does not affect precision unless the estimates are on the boundaries, which, as we will see later, is actually not the case.
} 
The set-up of our model allows us to study a number of different hypotheses. The first relates to the transmission of shocks from Germany. If we assume (as is common in the literature) that German government bonds are the benchmark bonds among the countries we study here, then shocks to German yields should lead to a substantial co-movement of all other yields, at least prior to the crisis. We can express this as

Hypothesis 1: Spillover coefficients from Germany to other markets are large and lead to co-movement. For the matrix $A$, this translates into $\alpha_{\text {Germany,j }}<0$.

For all remaining markets, we would expect little further spillovers for the pre-crisis period, since we are effectively looking at how the spreads relative to Germany co-move. This leads us to

Hypothesis 2: Spillover coefficients among all other markets are small. Normally, they should move yields in the same direction. Under flight to quality, ${ }^{6}$ they move yields in different directions. For the matrix $A$, this translates into

Integration: $\alpha_{i, j}<0$;

Flight to quality: $\alpha_{i, j}>0$ (for $i \neq$ Germany).

These hypotheses relate to the level of spillover coefficients, and we would expect these to hold in particular during the pre-crisis sample. We can also look at the change in the coefficients over time. This leads us to

\section{Hypothesis 3:}

If spillover coefficients change, this suggests

Contagion: $\Delta \alpha_{i, j}<0$;

Fragmentation: $\Delta \alpha_{i, j}>0$.

Note that these are the expected signs for the coefficients of $A$, while the opposite signs apply for $A^{-1}$.

\subsection{Data and estimation}

The objective of the paper is to test the three hypotheses for the transmission of shocks across different euro area sovereign bond markets. To keep the model tractable, the empirical analysis includes eight euro area countries: three core countries (Germany, France, the Netherlands) and five countries that experienced stress during the sovereign debt crisis (Greece, Ireland, Italy, Portugal and Spain).

We take the ten-year government bond yields for the mentioned eight euro area countries, given that these are the most liquid markets. Since shocks in financial markets tend to be

\footnotetext{
${ }^{6}$ We use the term flight to quality in a broad sense, and are agnostic about the underlying reasons-for instance, it could arise because of a flight toward countries with lower credit risk, or with lower liquidity risk.
} 
transmitted very rapidly, we choose a five-minute frequency for these data. ${ }^{7}$ The data source is Reuters. More precisely, we calculate the midpoint between the bid and ask, and take first differences. All of the series exhibit the typical characteristics of heteroskedasticity, skewness and excess kurtosis. Market opening hours are between 8 a.m and 6 p.m. ECT. We remove from our analysis the first thirty minutes and the last thirty minutes of each trading day in order to remove discontinuities potentially stemming from the beginning or end of the market operations, as well as a few large outliers.

We have data covering the period 14 August 2008 to 23 October 2013. In total, this means we have more than 155,000 five-minute observations for each of the eight countries. As noted above, we split the sample into three subperiods: a pre-crisis period, a crisis period and the time after the announcement of the OMT program.

The pre-crisis period covers from August 2008 (the soonest that the data are available to us) until 1 September 2009, when the newly elected Greek government announced for the first time that there could be problems with the Greek government debt data. The second period, which we will call the crisis period, starts on 1 March 2010, when Greek government bond yields started to rise substantially before the first Greek rescue package was agreed on 10 March 2010, and the ECB started its first bond-buying program. Note that the two periods are not adjacent-we omit the period between September 2009 and February 2010, since it is not clear to which regime it should be allocated. We end the crisis regime on 8 March 2012. On 9 March 2012, the Greek sovereign debt restructuring was declared, at which time Greek government bond yields dropped drastically (see Figure 1). Since we want to ensure that our analysis is not affected by this anomaly in the data, we end the crisis sample just beforehand. The third period starts on 1 October 2012-after Mr. Draghi's “Whatever-it-takes” speech in July, the ECB's official announcement of the OMT at the beginning of August and the announcement of the implementation details for the OMT in September 2012.

As to the estimation of model (2), this is implemented by first running a VAR with 4 lags. We then recover the reduced-form residuals, containing the contemporaneous spillover effects. From these reduced-form residuals, we then define the heteroskedastic regimes. We do this using two alternative approaches. For the first approach, which we call the "statistical" approach, we define a crisis country to be in a high-volatility regime if the VAR residuals are at least one standard deviation higher than the average over the full sample period, and remain elevated for a period of five days. In addition, we define one regime as occurring when more than one of the five crisis countries exhibits high volatility. Finally, there is a "tranquil" regime, when none of the countries exhibits high volatility. Table 1 shows the standard deviations for yields for each of the eight countries and each of the regimes. The table shows that, indeed, this identification detects well periods when individual countries are volatile while others are in a tranquil state.

Table 1 here

We then estimate the parameters by minimizing the distance

$$
\min g^{\prime} g \text { with } g=A^{\prime} \Sigma_{i} A-\Omega_{i}
$$

s.t. $\quad \Sigma_{i}$ is diagonal, $A$ restrictions,

\footnotetext{
${ }^{7}$ The use of intraday data to study the transmission of shocks to financial markets during the European sovereign debt crisis has also been advocated by Rogers et al. (2014) and Ghysels et al. (2014).
} 
with $\Sigma$ the variance of the structural shocks, and $\Omega$ the variance-covariance matrix for each regime. Identification requires the different equations to be linearly independent, which is satisfied by the fact that the volatility of one of the observed variables is higher, while the others are relatively stable. Since the model is overidentified - we need only two regimes but have seven-we can test the overidentifying restrictions.

To check for the robustness of this identification method, we also employ an alternative way of detecting volatility regimes. This second method, or what we call a "narrative" approach, identifies a country to be in a volatile regime if that particular country is the focus of the news on a particular day. We identify this by looking at Reuters News in Factiva. $^{8}$

Figure 2 shows the number of articles covering each of the five stressed euro area countries. The numbers shown are monthly totals, while the identification method uses daily data. This figure is meant for illustration only, since with daily data it is hard to get an intuitive picture of changes over time. The figure shows that media attention is well aligned with financial market stress. Greece, for instance, received a lot of attention in early 2010, when it came under intense market pressure and ultimately received a bailout program from the IMF and the EU.

Figure 2 here

As before, we identify a tranquil regime and regimes when one or more countries receive substantial media attention. A country is defined as receiving a lot of attention on a particular day if the number of stories about the economic situation in that country exceeds more than two standard deviations from what it usually receives, on a daily average, over the entire sample period.

We use a bootstrap with 200 replications to obtain the significance levels of our parameter estimates. For each of the regimes, we employ the estimated regime-specific variance-covariance matrix to create new data with the same covariance structure in each bootstrap replication. For each draw, we estimate the coefficients by minimizing the moments given the restrictions. Finally, we obtain variance decompositions.

Table 2 illustrates why it is important to conduct the analysis in a structural model that allows us to identify the nature of the shocks and leaves the spillover directions unrestricted. It shows coefficients of simple ordinary least square (OLS) regressions that explain national yield changes by the changes in German yields, which give us a sense of the unconditional correlation of yield changes. While all coefficients are positive and large in the pre-crisis sample, some of these turn negative during the crisis or under OMT. This switch in the sign of the correlations is likely explained by two factors: first, a change in the effects of shocks to peripheral countries, which initially led to a comovement of yields but during the crisis triggered a flight to quality toward the German bond market; and second, a shift in the relative importance of shocks, with shocks to the peripheral countries having become more important during the crisis. An analysis of correlations that does not condition on the source of shocks, or restricts the sign of their impact, will therefore not reveal the true nature of spillovers among euro area government bond markets and their evolution over time. A structural model is warranted.

\footnotetext{
${ }^{8}$ That is, we search Reuters News for the name of a given country or the corresponding adjective (e.g., "Greece or Greek") in the headline of the lead paragraph. We restrict our search to the "economic news" category. For similar approaches to identify the intensity of crisis-related news about specific countries, see Beetsma et al. (2013) and Ehrmann et al. (2014).
} 
Table 2 here

\section{Empirical Results}

We next report the empirical results, first focusing on the overall spillovers, before we compare direct and overall effects, study variance decompositions, and finally discuss the results of the robustness checks.

\subsection{Overall spillovers}

\section{Substantial co-movement of bond yields prior to the European crisis}

We start by testing our first two hypotheses for the pre-crisis period of 2008 and 2009. Table 3 presents the estimates for the overall spillovers from the matrix $A^{-1}$, including indirect spillovers via third markets. In Table 3 , as in the subsequent tables, the source country of the shock is depicted in the top row; the recipient countries for the impact of the shocks are given in the first column. Bold numbers show coefficients that are statistically significant at the $1 \%$ level. $^{9}$

Panel A of Table 3 shows results for the pre-crisis period, when markets were effectively responding to two types of shocks: they were either moving jointly in response to shocks to the German bond yield, or alternatively to idiosyncratic shocks that moved only one market, without much in terms of spillovers. The reaction coefficients to the first type of shock are provided in the leftmost column of the table, and show how shocks to German yields were transmitted to the other bond markets in a substantial manner, with spillover coefficients ranging from 0.8 to 0.9 . These coefficients imply that an increase (decrease) by 10 basis points in the 10-year Bund induced an increase (decline) in 10-year yields in other euro area countries by 8 to 9 basis points, and confirm our Hypothesis 1 .

\section{Table 3 here}

Beyond this shock, which moved all countries alike, markets were systematically responding in a significant fashion only to their own shocks (reported on the diagonal of the table). Apart from the first column and the diagonal elements, there are few statistically significant coefficients, and these are in addition mostly small in magnitude, confirming our Hypothesis 2.

However, there are exceptions to this pattern, in particular for shocks to Greek bond yields: the respective spillover coefficients to all countries except Portugal are negative, and statistically significant for the case of the Netherlands and Italy. This means that a rise (decline) in the pricing of Greece's sovereign risk induced a small but statistically significant decrease (increase) in yields among these countries. This is consistent with the flight-to-safety interpretation, in which investors reallocate their portfolios away from a country if risks in this country rise. But the reverse also holds: i.e., an exogenous decline in Greek bond yields induced capital flows into Greece. In short, the evidence suggests

\footnotetext{
${ }^{9}$ More detailed results, including standard errors, are provided as appendix tables.
} 
that Greek government bonds were already considered to constitute a different asset class during the global financial crisis and before the European sovereign debt crisis.

\section{Fragmentation and flight to safety during the height of the European crisis}

Moving on to the results for the crisis sample, reported in panel B of Table 3, two major points stand out. First, shocks to German bond yields were leading to considerably less co-movement across the other countries. Even though the spillover coefficients are estimated to be statistically significant, their magnitude has changed. French and Dutch bond yields still saw a reaction of similar magnitude than prior to the crisis, but for all other countries, spillovers were substantially smaller, and with the exception of Ireland statistically significantly so. The overall picture therefore suggests that markets in the euro area experienced fragmentation, not contagion, during the height of the crisis: domestic bond yields were driven much more by domestic idiosyncratic factors than by common factors. Fragmentation of markets is therefore the answer to our Hypothesis 3.

A second important change compared to the pre-crisis period is the presence of several statistically significant flight-to-quality phenomena, speaking to our Hypothesis 2. Shocks to yields in Italy, Portugal and Ireland triggered adverse reactions in German and French yields. For the case of Italy, these reactions were large in magnitude, with spillover coefficients of -0.21 and -0.15 , respectively (which are not only statistically significantly different from zero, but also from their pre-crisis figures).

\section{Italian and Spanish sovereign debt as a new asset class under OMT}

Turning to the OMT sample in panel $\mathrm{C}$ of Table 3, yet another picture emerges. First, with regard to Hypothesis 3, the fragmentation of government bond markets continued and intensified. German, French and Dutch yields co-moved very strongly in response to shocks to Germany. The other countries, in contrast, show either statistically insignificant or very small spillover coefficients - which are statistically significantly smaller than in the pre-crisis sample and in the crisis sample. Second, flight to quality became less of an issue. It is still present for shocks to Italy, but the magnitudes have become smaller, and it has become statistically insignificant for the other countries.

The most striking result, however, is the separation of the sovereign bond markets of Italy and Spain from those of the rest of the euro area. Before 2010, Italy's and Spain's bond markets were as integrated as, and did not behave differently from those of, e.g., France and the Netherlands. Subsequently, during the 2010-12 period, both countries saw a marked reduction in their co-movement with the other countries in response to shocks to German yields. In addition, Spanish yields started to be affected by shocks to Italian yields, but not vice versa. For the third subsample studied here, Italian and Spanish yields stopped reacting to German shocks, and effectively only moved in response to their own and each other's shocks. In short, the only robust evidence for the presence of contagion (which was a possible outcome under Hypothesis 3) in euro area sovereign debt markets is found for the relationship between Spain and Italy.

It is very difficult to gauge the extent to which the fragmentation, flight to quality and contagion between Spain and Italy were purely determined by market forces, or affected by policy. There were so many elements in the crisis response, both among governments and for the ECB, that it is hard to identify relevant policies and to trace their effects through all individual national bond markets. However, it is clear that widespread 
contagion did not occur, either because policy responses were highly effective or because concerns about contagion were exaggerated.

That contagion did eventually occur for Spain and Italy is consistent with the set-up of the ECB's OMT program, which is conditional on a country adopting a rescue program, fulfilling all the related conditions and still having full market access. This made it clear to investors that the OMT program was primarily targeted at preventing a run against Italy and Spain (and possibly other core countries). The smaller periphery countriesGreece, Ireland and Portugal—did not fulfill the conditions of the OMT program at that time.

Accordingly, a stronger co-movement of Spanish and Italian yields is to be expected. We recall from Figure 1 that Spanish and Italian yields declined from close to $7 \%$ in the summer of 2012 to around 3\% at the end of 2013. Hence the contagion from Italian to Spanish bond markets, and vice versa, was desirable from a policy perspective, since it reinforced the mutual reduction in yields during that time period.

In summary, the findings of the empirical analysis show that there was no contagion among euro area sovereign debt markets during the crisis between 2010 and 2012. The opposite is the case. While euro area bond markets were highly integrated before the European crisis, they became fragmented, or at least less integrated, from early 2010 onward. Since the OMT announcement in the summer of 2012, the integration of euro area bond markets has shown a diverging pattern, with an increased integration among the core countries and a disappearance of flight-to-quality phenomena. But there has also been a deepening of the fragmentation across country groups. Most importantly, Italy and Spain seem no longer to be part of the euro area core, and now constitute a country grouping by themselves, showing little integration with the rest of the euro area, but contagion between themselves.

\subsection{Direct and overall effects}

So far, we have studied the coefficients in the matrix $A^{-1}$, which provide estimates of the overall linkages among bond markets by allowing the transmission of a shock to one specific sovereign debt market to go through sovereign debt markets in other euro area countries. It is interesting to compare these to the direct effects, as estimated in matrix $A$ and reported in Table 4.

Table 4 here

Focusing on the first column, i.e. the shocks to German yields, a comparison of the overall effects and the direct effects indicates that, prior to the European crisis, there was a large difference between these two types of spillovers. On average, the overall spillovers were $75 \%$ larger than the direct transmission of shocks. By contrast, this difference between direct and overall spillovers became a lot smaller during the crisis, with the overall spillovers in many cases being only marginally larger than the direct ones.

The difference between direct and total spillover coefficients can be interpreted as an alternative measure of integration. In highly integrated financial markets, the transmission is likely to take place not only directly between two markets, but often via third markets. Two markets are less integrated not only if the overall transmission 
between the two declines, but also if there is less of an indirect effect via other markets. This is indeed the case: whereas in panel A of Table 4, which reports the results for the pre-crisis period, we can see a large number of statistically significant spillover effects, the fragmentation of euro area markets during the crisis is reflected in the fact that, for the other two periods, very few spillover effects are estimated to be significant. Hence, this comparison supports the findings of the previous section.

\subsection{Variance decompositions}

Having identified and analyzed the spillover coefficients, we next assess the economic importance of each of the bond markets for the entire system. Table 5 shows the variance decomposition for the reduced-form model (2) over the three subsamples. Each cell indicates the share of the total variance of each bond market that is explained by the respective shocks.

Table 5 here

In line with our previous results, we find that during the pre-crisis, there were mainly two relevant shocks - those to the German yields, which explain around 35\% of the variances of the other countries' yields, and the country's own idiosyncratic shocks, which on average account for $65 \%$ of the variances. That pattern changes substantially over the course of the crisis, especially for the stressed countries, corroborating the evidence for a fragmentation of markets: while German shocks on average explain 35\% of their variance during the pre-crisis period, this number drops to $21 \%$ at the height of the crisis, and to $5 \%$ under OMT. Own shocks, in contrast, explain an increasing share of the respective variance, averaging $60 \%, 77 \%$ and $84 \%$ over the three subperiods. The only notable exception is Spain under OMT, where only $53 \%$ of the variance is due to its own idiosyncratic shocks, whereas $32 \%$ of the variance is explained by shocks to Italian yields, confirming that contagion was not only statistically significant, but economically important.

\subsection{Robustness-identification using the narrative approach}

As discussed in section 2, the specification of different regimes is important for the identification of spillover effects. While we choose to use the statistical approach to identify periods when markets were particularly volatile, an alternative is the narrative approach, which identifies periods during which a country receives a high degree of media attention.

Tables 6 to 8 here

Tables 6 to 8 show the corresponding estimates. Two results stand out from the analysis using this alternative scheme. The first is that the results are robust. The transmission coefficients are, overall, very similar, independent of whether the narrative approach for the statistical approach is chosen. Of course, individual figures do change, but these 
changes are usually small, and they do not differ from the benchmark results in any systematic manner.

The second finding from the alternative exercise is that the coefficients for the spillovers tend to be statistically more significant than when using the statistical approach. For instance, according to these results, there are still flight-to-quality effects in the OMT subsample. The main results of this paper are, however, robust.

\section{Conclusions}

The empirical analysis of the paper shows that the euro area has experienced substantial fragmentation across national sovereign bond markets since the beginning of the European sovereign debt crisis in 2010. European bond markets were highly integrated before 2010 (possibly more than warranted, given that markets were not pricing much credit risk prior to the global financial crisis), with the German government bond market being the dominant one in driving yields all over the euro area. Beyond this general comovement, yields were largely determined only by shocks in the domestic market.

Since the start of the European crisis in 2010, this dominance of German yields has become considerably weaker, suggesting a general fragmentation of markets, which has strengthened further over time. In addition, we observe more cases of a flight to quality during the crisis, whereby shocks to yields in several stressed countries moved French and German yields in the opposite direction, a phenomenon that largely disappears after the ECB's announcement of its OMT program.

Importantly, however, there is generally no evidence of contagion; i.e., we typically do not find a strengthening in the transmission of sovereign risk shocks across euro area countries between 2010 and 2012. On the contrary, fragmentation means that the transmission of shocks had generally become weaker during that period, a finding that is in line with Caporin et al. (2013) and Claeys and Vašíček (2014). The only exception to this is the case of Italy and Spain. Both were part of the euro area core before the crisis, but started decoupling from the core euro area countries. This decoupling and separation of Italy and Spain intensified after the announcement of the OMT program in the summer of 2012, while the bidirectional spillovers among these two countries increased, constituting our only case of a contagious pattern. This finding is intriguing yet intuitive, since the OMT program was specifically targeted at Italy and Spain, while crisis countries without market access were not eligible for OMT purchases.

This raises a question about the role that policies, and in particular policies of the ECB, have played in all of this. While it is difficult to separate the impact of policies from market factors, our findings suggest that financial integration strengthened within core countries and within periphery countries, whereas across these country groups there was more fragmentation.

What do these findings imply for policy? On the one hand, the pattern of disintegration identified in this paper may be partly desirable, since it prevented a more systemic crisis in the euro area through stronger cross-country linkages. The findings of the paper are indeed remarkably strong in rejecting the contagion hypothesis, which dominated the policy discussions for much of the crisis. On the other hand, the high degree of fragmentation also poses difficult challenges for policy-makers currently and in the future, since it leads to an unequal transmission of the ECB's monetary policy to the various countries. It is therefore important to see whether and to what degree market integration will rise again once the crisis abates. 


\section{References}

Altavilla, C., D. Giannone and M. Lenza (2014). The Financial and Macroeconomic Effects of OMT Announcements. ECB Working Paper No. 1707.

Andersen, T., Bollerslev, T., Diebold, F. and C. Vega (2007). Real-Time Price Discovery in Stock, Bond and Foreign Exchange Markets. Journal of International Economics 73, 251-277.

Arghyrou, M. G. and K. Alexandros (2012). The EMU Sovereign-Debt Crisis: Fundamentals, Expectations and Contagion. Journal of International Financial Markets, Institutions and Money 22(4), 658-677.

Bae, K.-H., Karolyi, A. and Stulz, R. (2003). A New Approach to Measuring Financial Contagion. Review of Financial Studies 16, 717-763.

Battistini, N., M. Pagano and S. Simonelli (2014). Systemic Risk, Sovereign Yields and Bank Exposures in the Euro Crisis. Economic Policy 29(78), 203-251.

Beber, A., M.W. Brandt and K. A. Kavajecz (2009). Flight-to-Quality or Flight-to-Liquidity? Evidence from the Euro-Area Bond Market. The Review of Financial Studies 22(3), 925-957.

Beetsma, R., M. Giuliodori, F. de Jong and D. Widijanto (2013). Spread the News: The Impact of News on the European Sovereign Bond Markets During the Crisis. Journal of International Money and Finance 34, 83-101.

Beirne, J. and M. Fratzscher (2013). The Pricing of Sovereign Risk and Contagion During the European Sovereign Debt Crisis. Journal of International Money and Finance 34, 60-82.

Bekaert, G., M. Ehrmann, M. Fratzscher and A. Mehl (2014). Global Crises and Equity Market Contagion. Journal of Finance 69, 2597-2649.

Bekaert, G., R.J. Hodrick and X. Zhang (2009). International Stock Return Comovements. Journal of Finance 64, 2591-2626.

Caporin, M., L. Pelizzon, F. Ravazzolo and R. Rigobon (2013). Measuring Sovereign Contagion in Europe. NBER Working Paper No. 18741.

Claeys, P. and B. Vašíček (2014). Measuring Bilateral Spillover and Testing Contagion on Sovereign Bond Markets in Europe. Journal of Banking and Finance 46, 151-165.

D'Agostino, A. and M. Ehrmann (2014). The Pricing of G7 Sovereign Bond Spreads - The Times, They are A-Changin. Journal of Banking and Finance 14, 155-176.

Diebold, F. and K. Yilmaz (2009). Measuring Financial Asset Return and Volatility Spillovers, with Application to Global Equity Markets. Economic Journal 119, 158-171.

Dungey, M., and V. L. Martin (2007). Unravelling Financial Market Linkages During Crises. Journal of Applied Econometrics 22(1), 89-119.

Ehrmann, M., M. Fratzscher, R. Gürkaynak and E. Swanson (2011a). Convergence and Anchoring of Yield Curves in the Euro Area. Review of Economics and Statistics 93, 350-364. 
Ehrmann, M., M. Fratzscher and R. Rigobon (2011b). Stocks, Bonds, Money Markets and Exchange Rates: Measuring International Financial Transmission. Journal of Applied Econometrics 26(6), 948-974.

Ehrmann, M., C. Osbat, L. Uusküla and J. Strasky (2014). The Euro Exchange Rate During the European Sovereign Debt Crisis - Dancing to its Own Tune? Journal of International Money and Finance 49, 319-339.

Forbes, K.J. and R. Rigobon (2002). No Contagion, Only Interdependence: Measuring Stock Market Co-Movements. Journal of Finance 57(5), 2223-2261.

Garcia de Andoain, C., P. Hoffmann and S. Manganelli (2014). Fragmentation in the Euro Overnight Unsecured Money Market. Economics Letters 125(2), 298-302.

Ghysels, E., J. Idier, S. Manganelli and O. Vergote (2014). A High Frequency Assessment of the ECB Securities Markets Programme. ECB Working Paper No. 1642.

Giordano, R., M. Pericoli and P. Tommasino (2013). Pure or Wake-up-Call Contagion? Another Look at the EMU Sovereign Debt Crisis. International Finance 16(2), 131-160.

Goldstein, M. (1998). The Asian Financial Crisis: Causes, Cures, and Systematic Implications (Institute for International Economics, Washington, D.C.).

Hamao, Y., Masulis, R.W. and Ng, V. (1990). Correlations in Price Changes and Volatility Across International Stock Markets. Review of Financial Studies 3, 281-307.

King, M., Sentana, E.,Wadhwani, S. (1994). Volatility and Links Between National Stock Markets. Econometrica 62, 901-934.

Lin, W., Engle, R.F., Ito, T. (1994). Do Bulls and Bears Move Across Borders? International Transmission of Stock Returns and Volatility. Review of Financial Studies 7, 507-538.

Lucas, A., B. Schwaab and X. Zhang (2014). Conditional Euro Area Sovereign Default Risk. Journal of Business and Economic Statistics 32(2), 271-284.

Pelizzon, L., M.G. Subrahmanyam, D. Tomio and J. Uno (2014). Sovereign Credit Risk, Liquidity, and ECB Intervention: Deus ex Machina? Mimeo, www.ecb.europa.eu/events/pdf/conferences/140908/pelizzon.pdf.

Rigobon, R. (2003). Identification Through Heteroskedasticity. Review of Economics and Statistics 85, 777-792.

Rigobon, R. and Sack, B. (2003a). Measuring the Reaction of Monetary Policy to the Stock Market. Quarterly Journal of Economics 118, 639-669.

Rigobon, R. and Sack, B. (2003b). The Impact of Monetary Policy on Asset Prices. Journal of Monetary Economics 51, 1553-1575.

Rogers, J.H., C. Scotti and J.H. Wright (2014). Evaluating Asset-Market Effects of Unconventional Monetary Policy: a Multi-Country Review. Economic Policy 29(80), 749799. 
Sentana, E. and G. Fiorentini (2001). Identification, Estimation and Testing of Conditionally Heteroskedastic Factor Models. Journal of Econometrics 102, 143-164. 
Figure 1: Sovereign yields in the euro area

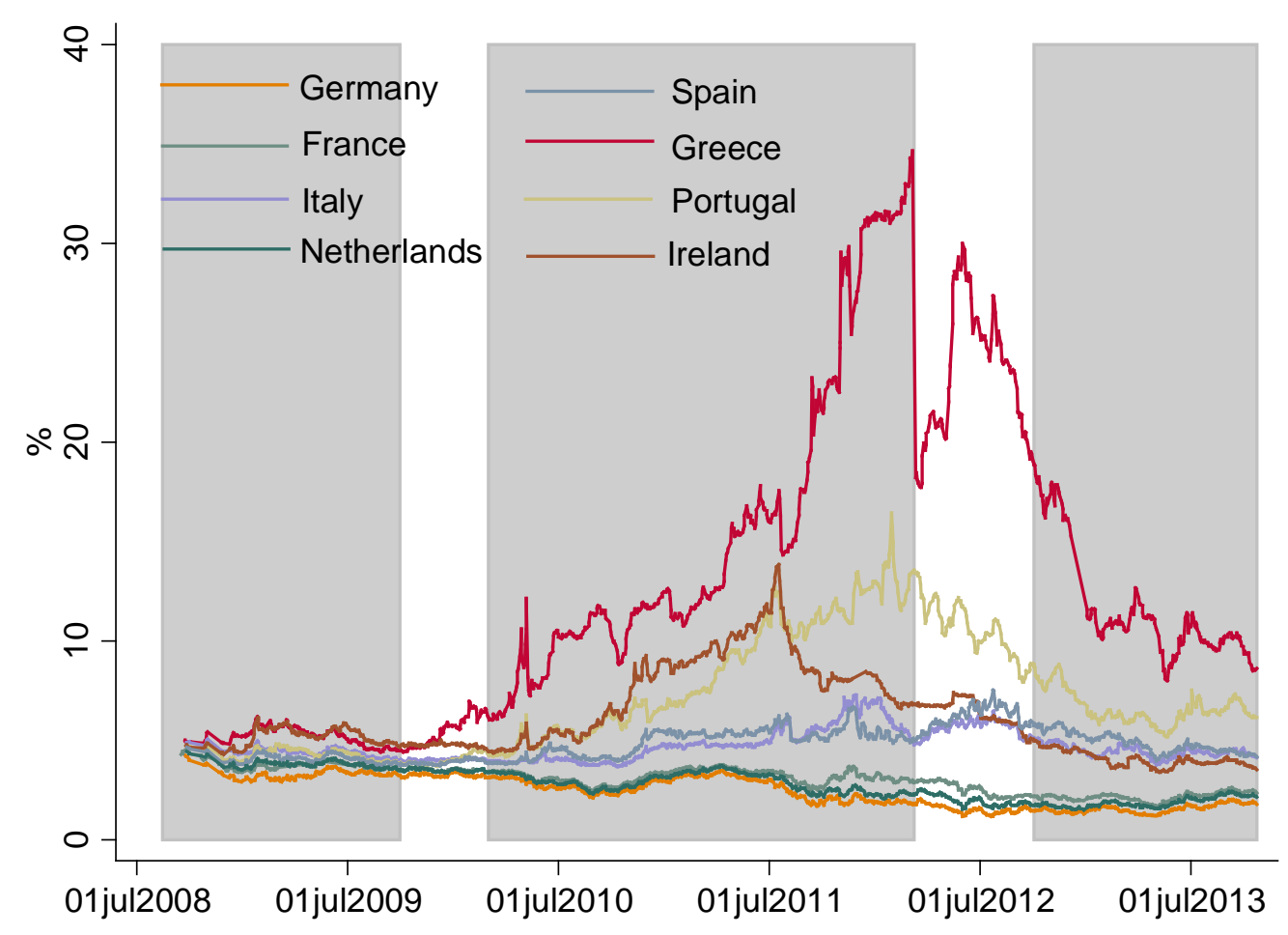

Notes: The figure shows the ten-year yields of the eight euro area countries included in the analysis of the paper. Shaded areas denote the three subsamples analyzed in this paper. 
Figure 2: Countries in the news

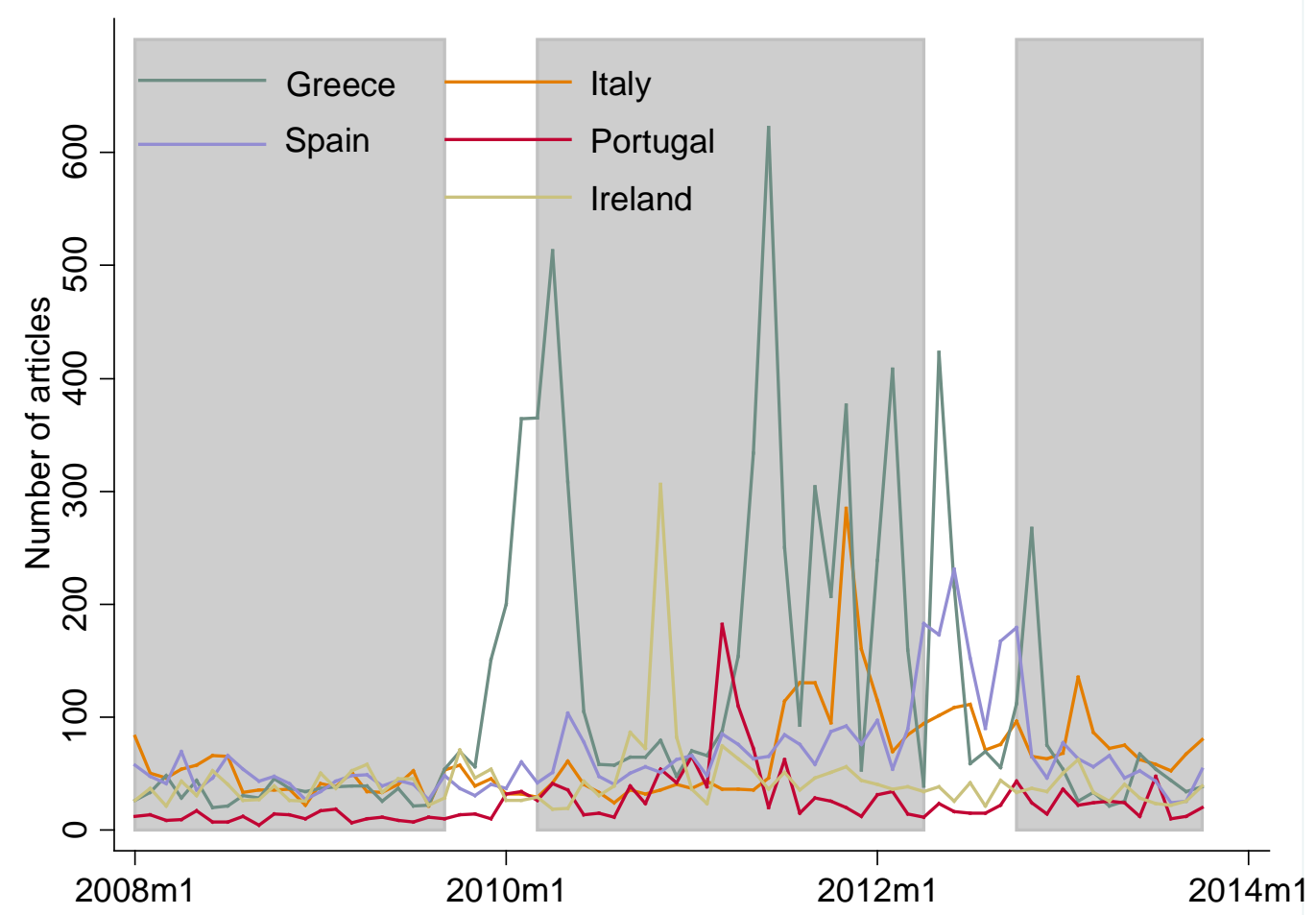

Notes: The figure shows the number of economic news stories in Reuters News on each of five of the euro area countries included in the analysis. For illustration purposes, the numbers shown are monthly totals, while the identification method uses daily data. Shaded areas denote the three subsamples analyzed in this paper. 
Table 1: Volatility regimes using a statistical approach for identification

\begin{tabular}{lccccccc}
\hline \hline Full sample & $\begin{array}{c}\text { All } \\
\text { variables } \\
\text { tranquil }\end{array}$ & $\begin{array}{c}\text { Italy } \\
\text { volatile }\end{array}$ & $\begin{array}{c}\text { Spain } \\
\text { volatile }\end{array}$ & $\begin{array}{c}\text { Greece } \\
\text { volatile }\end{array}$ & $\begin{array}{c}\text { Portugal } \\
\text { volatile }\end{array}$ & $\begin{array}{c}\text { Ireland } \\
\text { volatile }\end{array}$ & $\begin{array}{c}\text { Some } \\
\text { stressed } \\
\text { countries } \\
\text { volatile }\end{array}$ \\
\hline St.dev. Germany & 0.32 & 0.39 & 0.42 & 0.30 & 0.32 & 0.37 & 0.44 \\
St.dev. France & 0.55 & 0.71 & 0.68 & 0.44 & 0.45 & 0.56 & 0.65 \\
St.dev. Netherlands & 0.37 & 0.39 & 0.65 & 0.35 & 0.37 & 0.46 & 0.93 \\
St.dev. Italy & 0.35 & $\mathbf{0 . 8 8}$ & 0.52 & 0.40 & 0.43 & 0.39 & $\mathbf{0 . 7 4}$ \\
St.dev. Spain & 0.36 & 0.40 & $\mathbf{0 . 9 3}$ & 0.41 & 0.44 & 0.40 & $\mathbf{0 . 7 0}$ \\
St.dev. Greece & 0.65 & 0.59 & 0.69 & $\mathbf{2 . 2 3}$ & 0.73 & 0.74 & $\mathbf{4 . 7 4}$ \\
St.dev. Portugal & 0.45 & 0.48 & 0.63 & 0.50 & $\mathbf{1 . 3 1}$ & 0.48 & $\mathbf{1 . 8 8}$ \\
St.dev. Ireland & 0.51 & 0.58 & 0.59 & 0.46 & 0.51 & $\mathbf{1 . 3 6}$ & $\mathbf{1 . 5 6}$ \\
\hline Share of observations & 37.53 & 0.56 & 0.87 & 25.16 & 6.04 & 5.69 & 24.15 \\
\hline \hline
\end{tabular}

Notes: The table shows the average standard deviations of 5-minute yield changes for six different volatility regimes. The first column is the regime when all euro area countries have a low volatility of less than one standard deviation relative to the sample period. The subsequent five columns show the regimes when only one of the five crisis countries exhibits periods with a higher than one standard deviation of yield changes. And the last column is for a regime when more than one of the crisis countries exhibits high volatility. Numbers in bold represent the figures for the countries with high volatility. 
Table 2: Correlation of yields with Germany

\begin{tabular}{|c|c|c|c|c|}
\hline & Full sample & Pre-crisis & Crisis & OMT \\
\hline France & $\begin{array}{c}0.706^{\star \star \star} \\
(0.006)\end{array}$ & $\begin{array}{c}0.870 \star \star \star \\
(0.016)\end{array}$ & $\begin{array}{c}0.791^{\star \star \star} \\
(0.008)\end{array}$ & $\begin{array}{c}0.749 * \star \star \\
(0.012)\end{array}$ \\
\hline Netherlands & $\begin{array}{c}0.853^{\star \star *} \\
(0.006)\end{array}$ & $\begin{array}{c}0.769 * \star * \\
(0.014)\end{array}$ & $\begin{array}{c}0.889 * * * \\
(0.008)\end{array}$ & $\begin{array}{c}0.913^{\star * *} \\
(0.011)\end{array}$ \\
\hline Italy & $\begin{array}{c}0.079 * * * \\
(0.007)\end{array}$ & $\begin{array}{c}0.734^{\star \star \star} \\
(0.015)\end{array}$ & $\begin{array}{c}-0.045^{\star \star *} \\
(0.011)\end{array}$ & $\begin{array}{c}-0.225^{\star * \star} \\
(0.019)\end{array}$ \\
\hline Spain & $\begin{array}{c}0.335^{\star * *} \\
(0.006)\end{array}$ & $\begin{array}{l}0.772^{\star \star \star} \\
(0.015)\end{array}$ & $\begin{array}{c}0.343^{\star \star \star} \\
(0.010)\end{array}$ & $\begin{array}{c}-0.150^{\star \star \star} \\
(0.016)\end{array}$ \\
\hline Greece & $\begin{array}{c}0.456^{\star \star *} \\
(0.055)\end{array}$ & $\begin{array}{c}0.731^{\star * \star} \\
(0.018)\end{array}$ & $\begin{array}{c}0.467^{\star \star \star} \\
(0.114)\end{array}$ & $\begin{array}{c}0.010 \\
(0.041)\end{array}$ \\
\hline Portugal & $\begin{array}{c}0.469 * * * \\
(0.012)\end{array}$ & $\begin{array}{c}0.754^{\star \star \star} \\
(0.015)\end{array}$ & $\begin{array}{c}0.493^{\star \star \star} \\
(0.024)\end{array}$ & $\begin{array}{c}-0.046^{\star *} \\
(0.022)\end{array}$ \\
\hline Ireland & $\begin{array}{c}0.564^{\star \star \star} \\
(0.009)\end{array}$ & $\begin{array}{l}0.731^{\star * *} \\
(0.017)\end{array}$ & $\begin{array}{c}0.618 * \star * \\
(0.017)\end{array}$ & $\begin{array}{c}0.191^{\star * \star} \\
(0.014)\end{array}$ \\
\hline
\end{tabular}

Notes: The table reports results from simple OLS regressions of $y_{t}^{c}=\alpha^{c}+\beta^{c} y_{t}^{D E}+\varepsilon_{t}^{c}$, explaining the changes in yields in country $c$ by the changes in German yields, using robust standard errors. The regressions are conducted country by country, and separately for the different sample period. *** denotes statistical significance at the $1 \%$ levels. 


\section{Table 3: Parameter estimates of reduced-form model—statistical identification approach}

\section{A. Pre-crisis}

\begin{tabular}{llllccccc}
\hline \hline & Germany & France & Netherlands & Italy & Spain & Greece & Portugal & Ireland \\
\hline Germany & $\mathbf{1 . 1 0 3}$ & $\mathbf{0 . 0 6 7}$ & 0.102 & -0.019 & 0.030 & -0.004 & -0.025 & -0.012 \\
France & $\mathbf{0 . 8 2 0}$ & $\mathbf{1 . 0 4 6}$ & 0.187 & 0.061 & 0.011 & -0.032 & 0.013 & 0.005 \\
Netherlands & $\mathbf{0 . 8 2 5}$ & 0.053 & $\mathbf{1 . 0 6 4}$ & 0.005 & 0.017 & $\mathbf{- 0 . 0 3 0}$ & -0.052 & -0.006 \\
Italy & $\mathbf{0 . 8 6 4}$ & 0.025 & $\mathbf{0 . 3 0 8}$ & $\mathbf{0 . 9 8 4}$ & 0.076 & $\mathbf{- 0 . 0 4 7}$ & $\mathbf{0 . 0 8 1}$ & -0.013 \\
Spain & $\mathbf{0 . 8 3 8}$ & $\mathbf{0 . 0 8 8}$ & $\mathbf{0 . 3 2 2}$ & 0.050 & $\mathbf{1 . 0 2 7}$ & -0.008 & 0.008 & $\mathbf{0 . 0 4 0}$ \\
Greece & $\mathbf{0 . 8 8 5}$ & $\mathbf{0 . 1 4 3}$ & 0.353 & $\mathbf{0 . 2 7 9}$ & 0.087 & $\mathbf{0 . 9 7 7}$ & 0.011 & $\mathbf{0 . 0 5 9}$ \\
Portugal & $\mathbf{0 . 8 7 9}$ & 0.063 & $\mathbf{0 . 4 3 5}$ & 0.050 & 0.098 & 0.023 & $\mathbf{0 . 9 7 7}$ & 0.001 \\
Ireland & $\mathbf{0 . 8 6 7}$ & $\mathbf{0 . 0 9 3}$ & 0.187 & 0.045 & 0.044 & -0.009 & 0.004 & $\mathbf{0 . 9 9 2}$ \\
\hline \hline
\end{tabular}

\section{B. Crisis}

\begin{tabular}{|c|c|c|c|c|c|c|c|c|}
\hline & Germany & France & Netherlands & Italy & Spain & Greece & Portugal & Ireland \\
\hline Germany & $0.843^{a}$ & -0.074 & $0.016^{\mathrm{a}}$ & $-0.207^{A}$ & $-0.023^{a}$ & -0.001 & -0.009 & -0.016 \\
\hline France & 0.812 & 0.930 & $0.027^{\mathrm{A}}$ & $-0.150{ }^{A}$ & -0.029 & -0.002 & $-0.011^{a}$ & -0.011 \\
\hline Netherlands & 0.783 & -0.004 & $1.013^{a}$ & $-0.140^{\mathrm{a}}$ & 0.039 & -0.005 & -0.013 & -0.002 \\
\hline Italy & $0.310^{A}$ & -0.011 & $-0.011^{\mathrm{A}}$ & $0.928^{a}$ & $0.007^{\mathrm{a}}$ & $-0.003^{\mathrm{A}}$ & $-0.011^{\mathrm{A}}$ & 0.003 \\
\hline Spain & $0.482^{A}$ & 0.010 & $-0.014^{\mathrm{A}}$ & $0.264^{\text {A }}$ & $0.991^{\mathrm{a}}$ & 0.000 & -0.004 & $0.002^{\mathrm{a}}$ \\
\hline Greece & $0.585^{a}$ & -0.008 & $0.134^{\mathrm{A}}$ & 0.240 & 0.020 & $0.998^{a}$ & 0.004 & $-0.004^{a}$ \\
\hline Portugal & $0.581^{a}$ & 0.054 & $0.045^{\mathrm{A}}$ & 0.021 & $-0.035^{\mathrm{a}}$ & 0.006 & 0.993 & 0.002 \\
\hline Ireland & 0.710 & -0.061 & $-0.013^{\mathrm{A}}$ & $-0.185^{A}$ & -0.017 & -0.008 & 0.030 & 0.987 \\
\hline
\end{tabular}

\section{OMT}

\begin{tabular}{|c|c|c|c|c|c|c|c|c|}
\hline & Germany & France & Netherlands & Italy & Spain & Greece & Portugal & Ireland \\
\hline Germany & 0.973 & $0.179^{\mathrm{a}}$ & -0.148 & $\mathbf{- 0 . 1 3 1}{ }^{\mathrm{A}, \mathrm{b}}$ & -0.078 & -0.004 & -0.004 & -0.005 \\
\hline France & 0.788 & 0.977 & -0.449 & $0.051^{\mathrm{B}}$ & 0.249 & -0.002 & -0.013 & -0.012 \\
\hline Netherlands & $0.964^{a}$ & $0.299^{a}$ & 0.802 & $-0.121^{A}$ & -0.034 & $-0.005^{a}$ & 0.001 & 0.000 \\
\hline Italy & $0.467^{\mathrm{a}, \mathrm{b}}$ & -0.255 & -0.076 & $1.390^{\mathrm{A}, \mathrm{B}}$ & $0.639^{A, B}$ & $0.011^{\mathrm{A}, \mathrm{b}}$ & $-0.001^{\mathrm{A}}$ & -0.005 \\
\hline Spain & $0.421^{\mathrm{a}}$ & $-0.440^{a}$ & -0.068 & $\mathbf{0 . 8 2 7}{ }^{A, B}$ & $1.292^{\mathrm{A}, \mathrm{B}}$ & 0.004 & 0.005 & -0.006 \\
\hline Greece & $\mathbf{0 . 3 2 7}{ }^{\mathrm{A}, \mathrm{b}}$ & 0.084 & 0.033 & $-0.142^{\mathrm{A}, \mathrm{B}}$ & 0.206 & $0.997^{\mathrm{a}}$ & 0.038 & 0.023 \\
\hline Portugal & $\mathbf{0 . 0 3 3 ^ { A , B }}$ & 0.093 & $-0.609^{a, B}$ & 0.061 & 0.132 & 0.006 & 0.995 & -0.013 \\
\hline Ireland & $0.233^{\mathrm{A}, \mathrm{B}}$ & 0.151 & -0.135 & $-0.037^{\mathrm{a}, \mathrm{b}}$ & -0.018 & $0.004^{b}$ & $0.007^{b}$ & 0.998 \\
\hline
\end{tabular}

Notes: The table reports the parameter estimates of matrix A-inverse in model (2), obtained with the identification through heteroskedasticity using the statistical approach. The source country of the shock is depicted in the row at the top of the tables; the recipient countries for the impact of the shocks are given in the first column. Bold numbers show coefficients that are statistically significant at the $1 \%$ level. a and A denote statistically significant differences compared to the pre-crisis sample at the $5 \% / 1 \%$ level; b and B denote statistically significant differences compared to the crisis sample at the $5 \% / 1 \%$ level. The significance is judged through the p-value obtained in a bootstrap with 200 replications. 
Table 4: Parameter estimates of structural-form model-statistical identification approach

\section{A. Pre-crisis}

\begin{tabular}{lllllllll}
\hline \hline & Germany & France & Netherlands & Italy & Spain & Greece & Portugal & Ireland \\
\hline Germany & 1.000 & $\mathbf{- 0 . 0 5 9}$ & -0.093 & 0.024 & -0.031 & 0.001 & 0.019 & 0.013 \\
France & $\mathbf{- 0 . 6 0 8}$ & 1.000 & $\mathbf{- 0 . 0 9 4}$ & $\mathbf{- 0 . 0 7 9}$ & 0.015 & 0.024 & -0.027 & -0.016 \\
Netherlands & $\mathbf{- 0 . 7 6 8}$ & -0.007 & 1.000 & -0.028 & 0.003 & $\mathbf{0 . 0 2 5}$ & 0.036 & -0.005 \\
Italy & $\mathbf{- 0 . 5 7 2}$ & 0.026 & $\mathbf{- 0 . 1 9 5}$ & 1.000 & $\mathbf{- 0 . 0 4 8}$ & $\mathbf{0 . 0 4 3}$ & $\mathbf{- 0 . 1 0 9}$ & 0.004 \\
Spain & $\mathbf{- 0 . 4 7 0}$ & $\mathbf{- 0 . 0 3 5}$ & $\mathbf{- 0 . 2 1 5}$ & -0.053 & 1.000 & -0.003 & -0.027 & $\mathbf{- 0 . 0 4 8}$ \\
Greece & $\mathbf{- 0 . 2 9 1}$ & -0.093 & $\mathbf{- 0 . 1 8 0}$ & $\mathbf{- 0 . 2 7 7}$ & -0.049 & 1.000 & -0.004 & $\mathbf{- 0 . 0 6 5}$ \\
Portugal & $\mathbf{- 0 . 4 3 5}$ & -0.004 & $\mathbf{- 0 . 3 1 9}$ & $\mathbf{- 0 . 0 4 3}$ & $\mathbf{- 0 . 0 7 1}$ & $\mathbf{- 0 . 0 3 8}$ & 1.000 & -0.003 \\
Ireland & $\mathbf{- 0 . 6 2 7}$ & -0.042 & $\mathbf{- 0 . 0 8 0}$ & -0.053 & -0.017 & 0.001 & -0.019 & 1.000 \\
\hline \hline
\end{tabular}

B. Crisis

\begin{tabular}{|c|c|c|c|c|c|c|c|c|}
\hline & Germany & France & Netherlands & Italy & Spain & Greece & Portugal & Ireland \\
\hline Germany & 1.000 & 0.082 & $-0.016^{\mathrm{a}}$ & $0.229^{A}$ & $0.025^{\mathrm{a}}$ & 0.002 & 0.012 & 0.016 \\
\hline France & $-0.937^{a}$ & 1.000 & $-0.012^{a}$ & -0.052 & 0.008 & 0.001 & 0.002 & -0.004 \\
\hline Netherlands & -0.821 & $-0.062^{a}$ & 1.000 & -0.028 & -0.060 & $0.003^{\mathrm{a}}$ & 0.004 & -0.011 \\
\hline Italy & $-0.356^{A}$ & $-0.017^{\mathrm{a}}$ & $0.016^{\mathrm{A}}$ & 1.000 & -0.017 & $0.002^{\mathrm{A}}$ & $0.008^{\mathrm{A}}$ & -0.009 \\
\hline Spain & -0.394 & -0.047 & $0.018^{\mathrm{A}}$ & $-0.379^{A}$ & 1.000 & -0.001 & -0.004 & $-0.008^{A}$ \\
\hline Greece & -0.392 & -0.027 & -0.129 & -0.364 & -0.023 & 1.000 & -0.014 & $-0.001^{\mathrm{A}}$ \\
\hline Portugal & -0.500 & $-0.101^{a}$ & $-0.034^{\mathrm{A}}$ & -0.163 & $0.023^{a}$ & $-0.008^{a}$ & 1.000 & -0.011 \\
\hline Ireland & $-0.850^{A}$ & 0.001 & $0.028^{A}$ & 0.014 & -0.005 & 0.008 & -0.038 & 1.000 \\
\hline
\end{tabular}

\section{OMT}

\begin{tabular}{|c|c|c|c|c|c|c|c|c|}
\hline & Germany & France & Netherlands & Italy & Spain & Greece & Portugal & Ireland \\
\hline Germany & 1.000 & -0.170 & 0.103 & $0.075^{b}$ & 0.058 & 0.003 & 0.002 & 0.003 \\
\hline France & $-1.069^{a}$ & 1.000 & $0.353^{\mathrm{a}}$ & 0.058 & -0.277 & 0.001 & 0.009 & 0.005 \\
\hline Netherlands & $-0.878^{a}$ & $-0.143^{A, b}$ & 1.000 & $0.012^{\mathrm{a}}$ & -0.005 & $0.001^{\mathrm{a}}$ & $-0.007^{\mathrm{a}, \mathrm{b}}$ & -0.006 \\
\hline Italy & $-0.343^{a}$ & 0.077 & 0.033 & 1.000 & $\mathbf{- 0 . 5 2 8}{ }^{A, B}$ & $-0.010^{\mathrm{A}, \mathrm{b}}$ & $0.003^{\mathrm{A}}$ & 0.001 \\
\hline Spain & -0.515 & $\mathbf{0 . 3 3 9} 9^{\mathrm{a}, \mathrm{b}}$ & $0.117^{\mathrm{a}}$ & $\mathbf{- 0 . 6 4 5}{ }^{\mathrm{A}, \mathrm{B}}$ & 1.000 & 0.002 & -0.004 & $0.005^{\mathrm{A}}$ \\
\hline Greece & $-\mathbf{0 . 1 3 2}{ }^{\mathrm{a}, \mathrm{b}}$ & -0.071 & -0.139 & $0.244^{\mathrm{A}, \mathrm{B}}$ & -0.274 & 1.000 & -0.038 & -0.026 \\
\hline Portugal & -0.383 & -0.226 & $0.559^{\mathrm{A}, \mathrm{B}}$ & $0.022^{b}$ & -0.077 & $-0.005^{a}$ & 1.000 & 0.008 \\
\hline Ireland & $-\mathbf{0 . 2 0 9}{ }^{\mathrm{A}, \mathrm{B}}$ & -0.121 & 0.058 & 0.001 & 0.028 & $-0.005^{b}$ & $-0.010^{b}$ & 1.000 \\
\hline
\end{tabular}

Notes: The table reports the parameter estimates of matrix A in model (2), obtained with the identification through heteroskedasticity using the statistical approach. The source country of the shock is depicted in the row at the top of the tables; the recipient countries for the impact of the shocks are given in the first column. Bold numbers show coefficients that are statistically significant at the $1 \%$ level. a and A denote statistically significant differences compared to the pre-crisis sample at the $5 \% / 1 \%$ level; b and B denote statistically significant differences compared to the crisis sample at the $5 \% / 1 \%$ level. The significance is judged through the p-value obtained in a bootstrap with 200 replications. 
Table 5: Variance decomposition—statistical identification approach

A. Pre-crisis

\begin{tabular}{lcccccccc}
\hline \hline & Germany & France & Netherlands & Italy & Spain & Greece & Portugal & Ireland \\
\hline Germany & $\mathbf{0 . 9 8 6}$ & 0.008 & 0.004 & 0.000 & 0.001 & 0.000 & 0.000 & 0.000 \\
France & $\mathbf{0 . 2 1 2}$ & $\mathbf{0 . 7 8 0}$ & 0.006 & 0.001 & 0.000 & 0.001 & 0.000 & 0.000 \\
Netherlands & $\mathbf{0 . 5 3 8}$ & 0.005 & $\mathbf{0 . 4 5 3}$ & 0.000 & 0.000 & 0.002 & 0.002 & 0.000 \\
Italy & $\mathbf{0 . 4 1 1}$ & 0.001 & 0.026 & $\mathbf{0 . 5 5 3}$ & 0.002 & 0.003 & 0.003 & 0.000 \\
Spain & $\mathbf{0 . 4 5 6}$ & 0.011 & 0.034 & 0.002 & $\mathbf{0 . 4 9 4}$ & 0.000 & 0.000 & 0.003 \\
Greece & $\mathbf{0 . 2 3 8}$ & 0.014 & 0.019 & $\mathbf{0 . 0 2 5}$ & 0.002 & $\mathbf{0 . 7 0 0}$ & 0.000 & 0.003 \\
Portugal & $\mathbf{0 . 4 5 2}$ & 0.005 & 0.056 & 0.002 & 0.004 & 0.001 & $\mathbf{0 . 4 8 1}$ & 0.000 \\
Ireland & $\mathbf{0 . 2 2 9}$ & 0.006 & 0.005 & 0.001 & 0.000 & 0.000 & 0.000 & $\mathbf{0 . 7 5 9}$ \\
\hline \hline
\end{tabular}

B. Crisis

\begin{tabular}{lcccccccc}
\hline \hline & Germany & France & Netherlands & Italy & Spain & Greece & Portugal & Ireland \\
\hline Germany & $\mathbf{0 . 9 6 6}$ & 0.006 & 0.000 & $\mathbf{0 . 0 2 7}$ & 0.000 & 0.000 & 0.000 & 0.000 \\
France & $\mathbf{0 . 5 0 3}$ & $\mathbf{0 . 4 8 8}$ & 0.000 & $\mathbf{0 . 0 0 8}$ & 0.000 & 0.000 & 0.000 & 0.000 \\
Netherlands & $\mathbf{0 . 5 4 4}$ & 0.000 & $\mathbf{0 . 4 4 7}$ & 0.008 & 0.001 & 0.000 & 0.000 & 0.000 \\
Italy & $\mathbf{0 . 1 9 2}$ & 0.000 & 0.000 & $\mathbf{0 . 8 0 7}$ & 0.000 & 0.000 & 0.000 & 0.000 \\
Spain & $\mathbf{0 . 2 9 5}$ & 0.000 & 0.000 & $\mathbf{0 . 0 4 1}$ & $\mathbf{0 . 6 6 3}$ & 0.000 & 0.000 & 0.000 \\
Greece & $\mathbf{0 . 0 9 5}$ & 0.000 & 0.002 & 0.007 & 0.000 & $\mathbf{0 . 8 9 5}$ & 0.000 & 0.000 \\
Portugal & $\mathbf{0 . 2 1 5}$ & 0.001 & 0.001 & 0.000 & 0.000 & 0.000 & $\mathbf{0 . 7 8 3}$ & 0.000 \\
Ireland & $\mathbf{0 . 2 6 5}$ & 0.001 & 0.000 & $\mathbf{0 . 0 0 8}$ & 0.000 & 0.000 & 0.001 & $\mathbf{0 . 7 2 4}$ \\
\hline \hline
\end{tabular}

C. OMT

\begin{tabular}{lcccccccc}
\hline \hline & Germany & France & Netherlands & Italy & Spain & Greece & Portugal & Ireland \\
\hline Germany & $\mathbf{0 . 9 5 8}$ & 0.018 & 0.004 & 0.016 & 0.004 & 0.000 & 0.000 & 0.000 \\
France & $\mathbf{0 . 5 0 6}$ & $\mathbf{0 . 4 3 1}$ & 0.029 & 0.002 & 0.031 & 0.000 & 0.000 & 0.000 \\
Netherlands & $\mathbf{0 . 8 3 9}$ & 0.045 & 0.104 & 0.012 & 0.001 & 0.000 & 0.000 & 0.000 \\
Italy & 0.095 & 0.016 & 0.000 & $\mathbf{0 . 7 7 7}$ & 0.111 & 0.000 & 0.000 & 0.000 \\
Spain & 0.091 & 0.055 & 0.000 & $\mathbf{0 . 3 2 3}$ & $\mathbf{0 . 5 3 2}$ & 0.000 & 0.000 & 0.000 \\
Greece & 0.013 & 0.000 & 0.000 & 0.002 & 0.003 & $\mathbf{0 . 9 8 0}$ & 0.000 & 0.000 \\
Portugal & 0.000 & 0.002 & 0.024 & 0.001 & 0.004 & 0.000 & $\mathbf{0 . 9 6 9}$ & 0.000 \\
Ireland & 0.058 & 0.014 & 0.004 & 0.001 & 0.000 & 0.000 & 0.000 & $\mathbf{0 . 9 2 3}$ \\
\hline \hline
\end{tabular}

Notes: The table reports the share of the variance of each series that is explained by the various structural shocks. The source country of the shock is depicted in the row at the top of the tables; the recipient countries for the impact of the shocks are given in the first column. Bold numbers show coefficients that are statistically significant at the $1 \%$ level. The significance is judged through the p-value obtained in a bootstrap with 200 replications. 


\section{Table 6: Parameter estimates of reduced-form model-narrative identification approach}

\section{A. Pre-crisis}

\begin{tabular}{llllccccc}
\hline \hline & Germany & France & Netherlands & Italy & Spain & Greece & Portugal & Ireland \\
\hline Germany & $\mathbf{1 . 1 3 2}$ & $\mathbf{0 . 0 4 4}$ & $\mathbf{0 . 1 5 5}$ & $\mathbf{0 . 0 7 5}$ & $\mathbf{0 . 1 2 4}$ & $\mathbf{- 0 . 0 1 1}$ & $\mathbf{- 0 . 0 2 3}$ & $\mathbf{- 0 . 0 1 5}$ \\
France & $\mathbf{0 . 8 8 3}$ & $\mathbf{0 . 9 9 3}$ & -0.082 & $\mathbf{0 . 1 0 7}$ & $\mathbf{0 . 1 1 4}$ & $\mathbf{- 0 . 0 6 3}$ & -0.010 & $\mathbf{0 . 0 8 1}$ \\
Netherlands & $\mathbf{0 . 7 8 5}$ & $\mathbf{0 . 1 3 6}$ & $\mathbf{1 . 0 9 3}$ & 0.059 & $\mathbf{0 . 1 0 8}$ & 0.008 & $\mathbf{0 . 0 8 4}$ & 0.008 \\
Italy & $\mathbf{0 . 6 7 8}$ & $\mathbf{0 . 0 8 1}$ & $\mathbf{0 . 4 3 6}$ & $\mathbf{1 . 0 4 7}$ & $\mathbf{0 . 1 6 1}$ & $\mathbf{- 0 . 0 2 4}$ & $\mathbf{0 . 1 2 7}$ & $\mathbf{- 0 . 0 0 7}$ \\
Spain & $\mathbf{0 . 7 0 3}$ & $\mathbf{0 . 0 8 2}$ & $\mathbf{0 . 4 6 2}$ & $\mathbf{0 . 1 2 6}$ & $\mathbf{1 . 0 6 9}$ & $\mathbf{- 0 . 0 1 3}$ & $\mathbf{0 . 0 2 4}$ & $\mathbf{0 . 1 1 5}$ \\
Greece & $\mathbf{0 . 8 7 3}$ & $\mathbf{0 . 2 9 1}$ & 0.029 & $\mathbf{0 . 3 0 4}$ & $\mathbf{0 . 3 0 6}$ & $\mathbf{0 . 9 6 9}$ & $\mathbf{0 . 1 5 0}$ & $\mathbf{0 . 0 5 9}$ \\
Portugal & $\mathbf{0 . 8 9 8}$ & $\mathbf{0 . 0 6 5}$ & $\mathbf{0 . 1 9 5}$ & 0.053 & $\mathbf{0 . 2 0 7}$ & -0.015 & $\mathbf{0 . 9 8 2}$ & $\mathbf{- 0 . 0 4 6}$ \\
Ireland & $\mathbf{0 . 9 3 4}$ & $\mathbf{- 0 . 0 3 9}$ & $\mathbf{0 . 1 2 7}$ & $\mathbf{0 . 1 1 3}$ & -0.051 & $\mathbf{0 . 0 0 9}$ & $\mathbf{0 . 0 9 3}$ & $\mathbf{0 . 9 5 7}$ \\
\hline \hline
\end{tabular}

\section{B. Crisis}

\begin{tabular}{|c|c|c|c|c|c|c|c|c|}
\hline & Germany & France & Netherlands & Italy & Spain & Greece & Portugal & $\begin{array}{l}\text { Ireland } \\
\end{array}$ \\
\hline Germany & 1.078 & $0.226^{A}$ & $0.005^{\mathrm{A}}$ & $-0.221^{A}$ & $0.008^{\mathrm{A}}$ & $-0.002^{\mathrm{a}}$ & $-0.007^{\mathrm{a}}$ & 0.001 \\
\hline France & 0.691 & $1.144^{A}$ & $0.005^{\mathrm{a}}$ & $-0.174^{A}$ & 0.028 & $-0.003^{A}$ & -0.003 & $0.002^{\mathrm{A}}$ \\
\hline Netherlands & $0.908^{a}$ & $0.263^{\mathrm{A}}$ & $1.003^{A}$ & $-0.215^{A}$ & -0.006 & $-0.002^{\mathrm{a}}$ & $-0.009^{\mathrm{A}}$ & -0.015 \\
\hline Italy & $0.431^{a}$ & 0.111 & $0.004^{\mathrm{A}}$ & $0.940^{A}$ & 0.141 & $0.006^{\mathrm{A}}$ & $-0.013^{A}$ & $0.007^{\mathrm{a}}$ \\
\hline Spain & 0.506 & 0.106 & $0.007^{\mathrm{A}}$ & 0.138 & $1.035^{\mathrm{a}}$ & $0.005^{\mathrm{A}}$ & $-0.018^{a}$ & $0.009^{\mathrm{A}}$ \\
\hline Greece & 0.350 & 0.134 & -0.029 & $-0.359^{A}$ & $-0.018^{a}$ & $0.997^{A}$ & $0.019^{\mathrm{A}}$ & $0.027^{\mathrm{a}}$ \\
\hline Portugal & 0.595 & 0.164 & $0.028^{\mathrm{A}}$ & -0.006 & 0.121 & $0.005^{\mathrm{a}}$ & 0.994 & $0.015^{\mathrm{a}}$ \\
\hline Ireland & 0.608 & $0.258^{a}$ & 0.094 & $-0.145^{A}$ & 0.006 & $-0.006^{a}$ & $0.015^{\mathrm{A}}$ & $0.999^{a}$ \\
\hline
\end{tabular}

\section{OMT}

\begin{tabular}{|c|c|c|c|c|c|c|c|c|}
\hline & "Germany & France & Netherlands & Italy & Spain & Greece & Portugal & Ireland \\
\hline Germany & $1.466^{\mathrm{A}, \mathrm{b}}$ & $\mathbf{0 . 1 8 0}{ }^{\mathrm{A}, \mathrm{b}}$ & $0.617^{\mathrm{A}, \mathrm{B}}$ & $\mathbf{- 0 . 1 6 7 ^ { A , b }}$ & $-0.094^{a, b}$ & $-0.008^{\text {B }}$ & $-0.008^{a}$ & $\mathbf{- 0 . 0 8 7} 7^{a, b}$ \\
\hline France & $\mathbf{1 . 1 3 2} 2^{\mathrm{A}, \mathrm{b}}$ & $1.117^{\mathrm{A}, \mathrm{b}}$ & $0.429^{\mathrm{A}, \mathrm{B}}$ & $-0.127^{A}$ & $\mathbf{- 0 . 0 9 9} 9^{\mathrm{a}, \mathrm{b}}$ & $\mathbf{0 . 0 0 7}{ }^{\mathrm{A}, \mathrm{b}}$ & $0.002^{\mathrm{a}}$ & $\mathbf{- 0 . 0 5 9} 9^{\mathrm{A}, \mathrm{b}}$ \\
\hline Netherlands & $1.268^{\mathrm{A}, \mathrm{b}}$ & $\mathbf{0 . 2 5 7 ^ { \mathrm { A } , \mathrm { b } }}$ & $1.453^{\mathrm{A}, \mathrm{B}}$ & $-\mathbf{0 . 1 0 3}{ }^{\mathrm{A}, \mathrm{B}}$ & $-0.034^{\mathrm{a}}$ & $\mathbf{- 0 . 0 0 8}{ }^{a, b}$ & $-0.013^{A}$ & $\mathbf{- 0 . 0 9 7} 7^{\mathrm{a}, \mathrm{b}}$ \\
\hline Italy & $0.687^{b}$ & $0.514^{\mathrm{a}, \mathrm{b}}$ & $-1.366^{\mathrm{A}, \mathrm{B}}$ & $1.270^{\mathrm{A}, \mathrm{B}}$ & $\mathbf{0 . 9 0 9} 9^{A, B}$ & $\mathbf{0 . 0 3 5 ^ { A , B }}$ & $\mathbf{0 . 0 5 2 ^ { A , B }}$ & $0.048^{a, b}$ \\
\hline Spain & $0.289^{\mathrm{A}, \mathrm{b}}$ & $0.295^{\mathrm{a}}$ & $-1.187^{\mathrm{A}, \mathrm{B}}$ & $0.476^{\mathrm{A}, \mathrm{B}}$ & $1.309^{\mathrm{A}, \mathrm{B}}$ & $\mathbf{0 . 0 3 0}{ }^{\mathrm{A}, \mathrm{B}}$ & $\mathbf{0 . 0 5 9} 9^{\mathrm{a}, \mathrm{b}}$ & $-0.006^{\mathrm{A}}$ \\
\hline Greece & $0.402^{\mathrm{a}}$ & $\mathbf{- 0 . 9 6 2} 2^{\mathrm{A}, \mathrm{B}}$ & $1.331^{\mathrm{A}, \mathrm{B}}$ & $-0.284^{A}$ & $\mathbf{- 0 . 4 4 1}{ }^{\mathrm{A}, \mathrm{b}}$ & $0.969^{B}$ & $0.007^{\mathrm{A}}$ & $\mathbf{0 . 1 8 9}{ }^{a, b}$ \\
\hline ortugal & $0.101^{\mathrm{a}}$ & $-0.085^{a}$ & $-0.036^{a}$ & $-0.072^{A}$ & $-0.286^{A}$ & $0.010^{a}$ & $0.990^{b}$ & $-0.019^{\mathrm{a}}$ \\
\hline Ireland & $0.683^{a}$ & $0.067^{\mathrm{a}}$ & $0.734^{\mathrm{A}, \mathrm{B}}$ & $-0.089^{a}$ & $0.041^{\mathrm{a}}$ & $-\mathbf{0 . 0 1 6}{ }^{\mathrm{A}, \mathrm{b}}$ & $-0.006^{\mathrm{A}, \mathrm{b}}$ & $0.941^{b}$ \\
\hline
\end{tabular}

Notes: The table reports the parameter estimates of matrix A-inverse in model (2), obtained with the identification through heteroskedasticity using the narrative approach. The source country of the shock is depicted in the row at the top of the tables; the recipient countries for the impact of the shocks are given in the first column. Bold numbers show coefficients that are statistically significant at the $1 \%$ level. a and A denote statistically significant differences compared to the pre-crisis sample at the $5 \% / 1 \%$ level; b and B denote statistically significant differences compared to the crisis sample at the $5 \% / 1 \%$ level. The significance is judged through the p-value obtained in a bootstrap with 200 replications. 


\section{Table 7: Parameter estimates of structural-form model-narrative identification approach}

\section{A. Pre-crisis}

\begin{tabular}{llccccccc}
\hline \hline & Germany & France & Netherlands & Italy & Spain & Greece & Portugal & Ireland \\
\hline Germany & 1.000 & -0.023 & $\mathbf{- 0 . 0 8 6}$ & $\mathbf{- 0 . 0 5 9}$ & $\mathbf{- 0 . 1 0 4}$ & 0.008 & $\mathbf{0 . 0 3 7}$ & $\mathbf{0 . 0 3 1}$ \\
France & $\mathbf{- 0 . 8 3 4}$ & 1.000 & $\mathbf{0 . 2 4 7}$ & $\mathbf{- 0 . 0 5 4}$ & $\mathbf{- 0 . 0 4 2}$ & $\mathbf{0 . 0 5 3}$ & $\mathbf{- 0 . 0 2 1}$ & $\mathbf{- 0 . 0 9 9}$ \\
Netherlands & $\mathbf{- 0 . 5 1 1}$ & $\mathbf{- 0 . 1 0 2}$ & 1.000 & 0.004 & -0.007 & $\mathbf{- 0 . 0 2 2}$ & $\mathbf{- 0 . 0 9 5}$ & -0.010 \\
Italy & $\mathbf{- 0 . 2 5 7}$ & -0.020 & $\mathbf{- 0 . 3 1 7}$ & 1.000 & $\mathbf{- 0 . 0 7 1}$ & $\mathbf{0 . 0 2 1}$ & $\mathbf{- 0 . 1 1 0}$ & 0.010 \\
Spain & $\mathbf{- 0 . 2 3 9}$ & $\mathbf{- 0 . 0 2 7}$ & $\mathbf{- 0 . 3 5 1}$ & $\mathbf{- 0 . 0 7 3}$ & 1.000 & $\mathbf{0 . 0 1 2}$ & $\mathbf{0 . 0 1 8}$ & $\mathbf{- 0 . 1 1 9}$ \\
Greece & $\mathbf{- 0 . 3 1 4}$ & $\mathbf{- 0 . 2 6 4}$ & $\mathbf{0 . 1 9 1}$ & $\mathbf{- 0 . 2 1 9}$ & $\mathbf{- 0 . 1 8 2}$ & 1.000 & $\mathbf{- 0 . 1 4 3}$ & -0.032 \\
Portugal & $\mathbf{- 0 . 7 3 7}$ & -0.019 & -0.043 & 0.012 & $\mathbf{- 0 . 1 0 3}$ & $\mathbf{0 . 0 0 5}$ & 1.000 & $\mathbf{0 . 0 5 1}$ \\
Ireland & $\mathbf{- 0 . 8 4 9}$ & $\mathbf{0 . 0 8 1}$ & -0.018 & $\mathbf{- 0 . 0 6 6}$ & $\mathbf{0 . 1 7 4}$ & -0.014 & $\mathbf{- 0 . 1 0 6}$ & 1.000 \\
\hline \hline
\end{tabular}

\section{B. Crisis}

\begin{tabular}{|c|c|c|c|c|c|c|c|c|}
\hline & Germany & France & "Netherlands & Italy & Spain & Greece & Portugal & $\begin{array}{l}\text { Ireland } \\
\end{array}$ \\
\hline Germany & 1.000 & $-0.214^{A}$ & $-0.005^{\mathrm{A}}$ & $0.198^{\mathrm{A}}$ & $-0.030^{a}$ & $-0.000^{\mathrm{a}}$ & $0.009^{A}$ & $-0.002^{A}$ \\
\hline France & $-0.642^{a}$ & 1.000 & $-0.001^{\mathrm{A}}$ & $0.039^{A}$ & -0.027 & $0.002^{\mathrm{A}}$ & $-0.002^{a}$ & $-0.001^{\mathrm{A}}$ \\
\hline Netherlands & $-0.819^{A}$ & -0.075 & 1.000 & 0.023 & 0.011 & $0.001^{\mathrm{A}}$ & $0.003^{\mathrm{A}}$ & 0.015 \\
\hline Italy & -0.323 & -0.019 & $-0.002^{\mathrm{A}}$ & 1.000 & $-0.134^{a}$ & $-0.006^{\mathrm{A}}$ & $0.009^{A}$ & $-0.005^{a}$ \\
\hline Spain & -0.376 & 0.006 & $-0.004^{\mathrm{A}}$ & $-0.238^{A}$ & 1.000 & $-0.004^{\mathrm{A}}$ & 0.012 & $-0.007^{A}$ \\
\hline Greece & -0.392 & $-0.065^{a}$ & $0.034^{\mathrm{a}}$ & $0.283^{\mathrm{a}}$ & -0.014 & 1.000 & $-0.017^{a}$ & -0.028 \\
\hline Portugal & $-0.418^{a}$ & -0.033 & -0.023 & -0.092 & -0.101 & -0.005 & 1.000 & $-0.014^{a}$ \\
\hline Ireland & -0.406 & -0.124 & -0.090 & 0.017 & $0.001^{\mathrm{a}}$ & $0.004^{\mathrm{a}}$ & $-0.019^{a}$ & 1.000 \\
\hline
\end{tabular}

\section{OMT}

\begin{tabular}{|c|c|c|c|c|c|c|c|c|}
\hline & "Germany & France & Netherlands & Italy & Spain & Greece & Portugal & Ireland \\
\hline Germany & 1.000 & $\mathbf{- 0 . 1 2 6}{ }^{A, B}$ & $\mathbf{- 0 . 3 3 2}{ }^{\mathrm{a}, \mathrm{B}}$ & $0.103^{A, B}$ & $-0.018^{a}$ & $0.004^{\mathrm{a}, \mathrm{b}}$ & $0.000^{\mathrm{A}}$ & $0.044^{b}$ \\
\hline France & -0.828 & 1.000 & $0.074^{\mathrm{a}, \mathrm{b}}$ & $\mathbf{- 0 . 0 1 6}{ }^{\mathrm{a}, \mathrm{b}}$ & $\mathbf{0 . 0 2 3} 3^{\mathrm{A}, \mathrm{b}}$ & $\mathbf{- 0 . 0 1 4} 4^{A, B}$ & $-0.008^{a}$ & $-0.003^{\mathrm{A}}$ \\
\hline Netherlands & $-0.799^{A}$ & $-0.083^{a}$ & 1.000 & $\mathbf{- 0 . 0 2 2} 2^{\mathrm{a}, \mathrm{b}}$ & -0.020 & $\mathbf{0 . 0 0 4} 4^{\mathrm{A}, \mathrm{b}}$ & $0.009^{A}$ & $0.024^{a}$ \\
\hline Italy & $\mathbf{- 0 . 6 8 8}{ }^{\mathrm{A}, \mathrm{b}}$ & $\mathbf{- 0 . 3 3 0}$ & $0.757^{\mathrm{A}, \mathrm{B}}$ & 1.000 & $\mathbf{- 0 . 7 5 1}{ }^{A, B}$ & $-0.011^{A}$ & $-0.003^{\mathrm{A}}$ & $\mathbf{- 0 . 0 6 1} 1^{A, B}$ \\
\hline Spain & $-0.479^{A}$ & $\mathbf{- 0 . 1 7 6}{ }^{A, B}$ & $0.683^{A, B}$ & $\mathbf{- 0 . 4 0 2}{ }^{\mathrm{A}, \mathrm{B}}$ & 1.000 & $\mathbf{- 0 . 0 1 3 ^ { A , B }}$ & $\mathbf{- 0 . 0 3 3 ^ { A , b }}$ & $\mathbf{0 . 0 4 4} 4^{\mathrm{A}, \mathrm{b}}$ \\
\hline Greece & $-0.537^{A}$ & $\mathbf{0 . 9 6 7} 7^{\mathrm{A}, \mathrm{B}}$ & $\mathbf{- 0 . 5 3 2}{ }^{\mathrm{A}, \mathrm{B}}$ & $0.072^{\mathrm{A}}$ & $0.306^{\mathrm{A}, \mathrm{b}}$ & 1.000 & $-0.043^{a}$ & $\mathbf{- 0 . 2 4 7} 7^{\mathrm{a}, \mathrm{b}}$ \\
\hline Portugal & $-0.387^{A}$ & $0.013^{a}$ & $0.324^{\mathrm{A}, \mathrm{B}}$ & $-0.056^{a}$ & $0.233^{A}$ & $-0.016^{a}$ & 1.000 & $0.026^{\mathrm{a}, \mathrm{b}}$ \\
\hline Ireland & $\mathbf{- 0 . 0 9 9}{ }^{\mathrm{A}, \mathrm{b}}$ & $0.079^{\mathrm{a}}$ & $\mathbf{- 0 . 5 1 0}{ }^{\mathrm{A}, \mathrm{B}}$ & $0.056^{A}$ & $-0.081^{A}$ & $0.012^{a}$ & $-0.000^{a}$ & 1.000 \\
\hline
\end{tabular}

Notes: The table reports the parameter estimates of matrix A in model (2), obtained with the identification through heteroskedasticity using the narrative approach. The source country of the shock is depicted in the row at the top of the tables; the recipient countries for the impact of the shocks are given in the first column. Bold numbers show coefficients that are statistically significant at the $1 \%$ level. a and A denote statistically significant differences compared to the pre-crisis sample at the 5\%/1\% level; b and B denote statistically significant differences compared to the crisis sample at the $5 \% / 1 \%$ level. The significance is judged through the p-value obtained in a bootstrap with 200 replications. 
Table 8: Variance decomposition-narrative identification approach

A. Pre-crisis

\begin{tabular}{lcccccccc}
\hline \hline & Germany & France & Netherlands & Italy & Spain & Greece & Portugal & Ireland \\
\hline Germany & $\mathbf{0 . 9 5 2}$ & 0.004 & 0.018 & 0.007 & 0.017 & 0.000 & 0.001 & 0.001 \\
France & $\mathbf{0 . 2 2 5}$ & $\mathbf{0 . 7 5 0}$ & 0.002 & 0.006 & 0.006 & $\mathbf{0 . 0 0 5}$ & 0.000 & $\mathbf{0 . 0 0 7}$ \\
Netherlands & $\mathbf{0 . 3 2 0}$ & $\mathbf{0 . 0 2 6}$ & $\mathbf{0 . 6 3 3}$ & 0.003 & $\mathbf{0 . 0 0 9}$ & 0.000 & $\mathbf{0 . 0 0 9}$ & 0.000 \\
Italy & $\mathbf{0 . 1 7 6}$ & 0.007 & $\mathbf{0 . 0 7 4}$ & $\mathbf{0 . 7 1 2}$ & $\mathbf{0 . 0 1 5}$ & 0.001 & $\mathbf{0 . 0 1 5}$ & 0.000 \\
Spain & $\mathbf{0 . 1 9 5}$ & $\mathbf{0 . 0 0 7}$ & $\mathbf{0 . 0 8 6}$ & 0.011 & $\mathbf{0 . 6 8 2}$ & 0.000 & 0.001 & $\mathbf{0 . 0 1 8}$ \\
Greece & $\mathbf{0 . 1 3 1}$ & $\mathbf{0 . 0 3 8}$ & 0.000 & $\mathbf{0 . 0 2 7}$ & $\mathbf{0 . 0 2 4}$ & $\mathbf{0 . 7 6 8}$ & $\mathbf{0 . 0 0 9}$ & 0.002 \\
Portugal & $\mathbf{0 . 2 4 4}$ & 0.003 & 0.012 & 0.001 & $\mathbf{0 . 0 2 0}$ & 0.000 & $\mathbf{0 . 7 1 7}$ & 0.002 \\
Ireland & $\mathbf{0 . 2 1 1}$ & 0.001 & 0.004 & 0.005 & 0.001 & 0.000 & 0.005 & $\mathbf{0 . 7 7 2}$ \\
\hline \hline
\end{tabular}

B. Crisis

\begin{tabular}{lcccccccc}
\hline \hline & Germany & France & Netherlands & Italy & Spain & Greece & Portugal & Ireland \\
\hline Germany & $\mathbf{0 . 8 9 4}$ & 0.059 & 0.000 & $\mathbf{0 . 0 4 7}$ & 0.000 & 0.000 & 0.001 & 0.000 \\
France & $\mathbf{0 . 1 9 3}$ & $\mathbf{0 . 7 9 0}$ & 0.000 & $\mathbf{0 . 0 1 5}$ & 0.000 & 0.000 & 0.000 & 0.000 \\
Netherlands & $\mathbf{0 . 1 9 0}$ & 0.024 & $\mathbf{0 . 7 7 2}$ & $\mathbf{0 . 0 1 3}$ & 0.000 & 0.000 & 0.000 & 0.001 \\
Italy & $\mathbf{0 . 1 3 9}$ & 0.014 & 0.000 & $\mathbf{0 . 8 2 5}$ & 0.016 & 0.003 & 0.002 & 0.000 \\
Spain & $\mathbf{0 . 1 7 1}$ & 0.011 & 0.000 & $\mathbf{0 . 0 1 6}$ & $\mathbf{0 . 7 9 7}$ & 0.002 & 0.003 & 0.001 \\
Greece & 0.001 & 0.000 & 0.000 & 0.001 & 0.000 & $\mathbf{0 . 9 9 7}$ & 0.000 & 0.000 \\
Portugal & 0.026 & 0.003 & 0.000 & 0.000 & 0.001 & 0.000 & $\mathbf{0 . 9 6 9}$ & 0.000 \\
Ireland & 0.027 & 0.007 & 0.002 & 0.002 & 0.000 & 0.000 & 0.000 & $\mathbf{0 . 9 6 1}$ \\
\hline \hline
\end{tabular}

C. OMT

\begin{tabular}{lcccccccc}
\hline \hline & Germany & France & Netherlands & Italy & Spain & Greece & Portugal & Ireland \\
\hline Germany & $\mathbf{0 . 8 5 5}$ & $\mathbf{0 . 0 1 7}$ & 0.077 & $\mathbf{0 . 0 2 9}$ & $\mathbf{0 . 0 0 8}$ & $\mathbf{0 . 0 0 2}$ & 0.000 & $\mathbf{0 . 0 1 1}$ \\
France & $\mathbf{0 . 4 1 6}$ & $\mathbf{0 . 5 2 7}$ & 0.030 & $\mathbf{0 . 0 1 4}$ & $\mathbf{0 . 0 0 7}$ & 0.001 & 0.000 & 0.004 \\
Netherlands & $\mathbf{0 . 5 6 6}$ & $\mathbf{0 . 0 3 0}$ & $\mathbf{0 . 3 7 9}$ & $\mathbf{0 . 0 1 0}$ & 0.001 & $\mathbf{0 . 0 0 1}$ & $\mathbf{0 . 0 0 1}$ & $\mathbf{0 . 0 1 2}$ \\
Italy & 0.059 & $\mathbf{0 . 0 4 3}$ & 0.119 & $\mathbf{0 . 5 2 6}$ & $\mathbf{0 . 2 3 8}$ & $\mathbf{0 . 0 1 0}$ & $\mathbf{0 . 0 0 4}$ & $\mathbf{0 . 0 0 1}$ \\
Spain & 0.015 & $\mathbf{0 . 0 2 0}$ & 0.130 & $\mathbf{0 . 1 0 6}$ & $\mathbf{0 . 7 1 1}$ & $\mathbf{0 . 0 1 0}$ & $\mathbf{0 . 0 0 7}$ & 0.000 \\
Greece & 0.003 & $\mathbf{0 . 0 1 9}$ & 0.014 & $\mathbf{0 . 0 0 3}$ & $\mathbf{0 . 0 0 7}$ & $\mathbf{0 . 9 5 1}$ & 0.000 & $\mathbf{0 . 0 0 2}$ \\
Portugal & 0.001 & 0.001 & 0.000 & 0.001 & $\mathbf{0 . 0 1 7}$ & $\mathbf{0 . 0 0 1}$ & $\mathbf{0 . 9 8 0}$ & 0.000 \\
Ireland & $\mathbf{0 . 1 1 3}$ & 0.001 & 0.066 & $\mathbf{0 . 0 0 5}$ & 0.001 & $\mathbf{0 . 0 0 4}$ & 0.000 & $\mathbf{0 . 8 0 9}$ \\
\hline \hline
\end{tabular}

Notes: The table reports the share of the variance of each series that is explained by the various structural shocks. The source country of the shock is depicted in the row at the top of the tables; the recipient countries for the impact of the shocks are given in the first column. Bold numbers show coefficients that are statistically significant at the $1 \%$ level. The significance is judged through the p-value obtained in a bootstrap with 200 replications. 


\section{Appendix}

Table A1: Parameter estimates and bootstrap results of reduced-form model, statistical identification

\begin{tabular}{|c|c|c|c|c|c|c|c|c|c|c|}
\hline \multicolumn{2}{|c|}{ Transmission } & \multicolumn{3}{|c|}{ Pre-crisis } & \multicolumn{3}{|c|}{ Crisis } & \multicolumn{3}{|c|}{ OMT } \\
\hline \multirow[t]{2}{*}{ From: } & \multirow[t]{2}{*}{ To: } & \multirow[t]{2}{*}{ Estimate } & \multicolumn{2}{|c|}{ Bootstrap } & \multirow[t]{2}{*}{ Estimate } & \multicolumn{2}{|c|}{ Bootstrap } & \multirow[t]{2}{*}{ Estimate } & \multicolumn{2}{|c|}{ Bootstrap } \\
\hline & & & Mean & Std. dev. & & Mean & Std. dev. & & Mean & Std. dev. \\
\hline \multirow[t]{8}{*}{ Germany } & Germany & 1.103 & 1.149 & 0.078 & 0.843 & 0.943 & 0.101 & 0.973 & 1.068 & 0.196 \\
\hline & France & 0.820 & 0.850 & 0.063 & 0.812 & 0.791 & 0.055 & 0.788 & 0.826 & 0.193 \\
\hline & Netherlands & 0.825 & 0.801 & 0.070 & 0.783 & 0.856 & 0.075 & 0.964 & 1.017 & 0.142 \\
\hline & Italy & 0.864 & 0.860 & 0.046 & 0.310 & 0.301 & 0.023 & 0.467 & 0.527 & 0.169 \\
\hline & Spain & 0.838 & 0.844 & 0.037 & 0.482 & 0.514 & 0.040 & 0.421 & 0.470 & 0.166 \\
\hline & Greece & 0.885 & 0.886 & 0.041 & 0.585 & 0.627 & 0.072 & 0.327 & 0.279 & 0.161 \\
\hline & Portugal & 0.879 & 0.865 & 0.053 & 0.581 & 0.627 & 0.063 & 0.033 & 0.015 & 0.115 \\
\hline & Ireland & 0.867 & 0.899 & 0.064 & 0.710 & 0.807 & 0.116 & 0.233 & 0.231 & 0.114 \\
\hline \multirow[t]{8}{*}{ France } & Germany & 0.067 & 0.069 & 0.023 & -0.074 & 0.031 & 0.110 & 0.179 & 0.215 & 0.091 \\
\hline & France & 1.046 & 1.045 & 0.018 & 0.930 & 1.012 & 0.083 & 0.977 & 1.045 & 0.091 \\
\hline & Netherlands & 0.053 & 0.050 & 0.025 & -0.004 & 0.091 & 0.104 & 0.299 & 0.319 & 0.096 \\
\hline & Italy & 0.025 & 0.027 & 0.029 & -0.011 & 0.036 & 0.054 & -0.255 & -0.191 & 0.173 \\
\hline & Spain & 0.088 & 0.087 & 0.023 & 0.010 & 0.073 & 0.067 & -0.440 & -0.287 & 0.195 \\
\hline & Greece & 0.143 & 0.138 & 0.040 & -0.008 & 0.068 & 0.097 & 0.084 & 0.082 & 0.125 \\
\hline & Portugal & 0.063 & 0.063 & 0.030 & 0.054 & 0.123 & 0.087 & 0.093 & 0.091 & 0.130 \\
\hline & Ireland & 0.093 & 0.094 & 0.028 & -0.061 & 0.033 & 0.106 & 0.151 & 0.133 & 0.065 \\
\hline \multirow[t]{8}{*}{ Netherlands } & s Germany & 0.102 & 0.161 & 0.100 & 0.016 & 0.018 & 0.011 & -0.148 & -0.055 & 0.274 \\
\hline & France & 0.187 & 0.238 & 0.086 & 0.027 & 0.029 & 0.014 & -0.449 & -0.298 & 0.346 \\
\hline & Netherlands & 1.064 & 1.091 & 0.048 & 1.013 & 1.012 & 0.010 & 0.802 & 0.887 & 0.254 \\
\hline & Italy & 0.308 & 0.346 & 0.067 & -0.011 & -0.008 & 0.033 & -0.076 & -0.117 & 0.338 \\
\hline & Spain & 0.322 & 0.358 & 0.066 & -0.014 & -0.010 & 0.020 & -0.068 & -0.179 & 0.342 \\
\hline & Greece & 0.353 & 0.390 & 0.071 & 0.134 & 0.131 & 0.063 & 0.033 & 0.022 & 0.209 \\
\hline & Portugal & 0.435 & 0.471 & 0.070 & 0.045 & 0.042 & 0.034 & -0.609 & -0.609 & 0.244 \\
\hline & Ireland & 0.187 & 0.239 & 0.096 & -0.013 & -0.010 & 0.023 & -0.135 & -0.078 & 0.172 \\
\hline \multirow[t]{8}{*}{ Italy } & Germany & -0.019 & -0.003 & 0.038 & -0.207 & -0.188 & 0.022 & -0.131 & -0.133 & 0.030 \\
\hline & France & 0.061 & 0.072 & 0.037 & -0.150 & -0.145 & 0.020 & 0.051 & 0.059 & 0.045 \\
\hline & Netherlands & 0.005 & 0.017 & 0.033 & -0.140 & -0.130 & 0.073 & -0.121 & -0.122 & 0.034 \\
\hline & Italy & 0.984 & 0.994 & 0.027 & 0.928 & 0.939 & 0.014 & 1.390 & 1.409 & 0.060 \\
\hline & Spain & 0.050 & 0.061 & 0.032 & 0.264 & 0.276 & 0.019 & 0.827 & 0.798 & 0.038 \\
\hline & Greece & 0.279 & 0.292 & 0.041 & 0.240 & 0.238 & 0.089 & -0.142 & -0.143 & 0.111 \\
\hline & Portugal & 0.050 & 0.062 & 0.036 & 0.021 & 0.030 & 0.074 & 0.061 & 0.061 & 0.057 \\
\hline & Ireland & 0.045 & 0.056 & 0.039 & -0.185 & -0.164 & 0.040 & -0.037 & -0.029 & 0.030 \\
\hline
\end{tabular}

(continued) 
Table A1 (continued): Parameter estimates and bootstrap results of reduced-form model, statistical identification

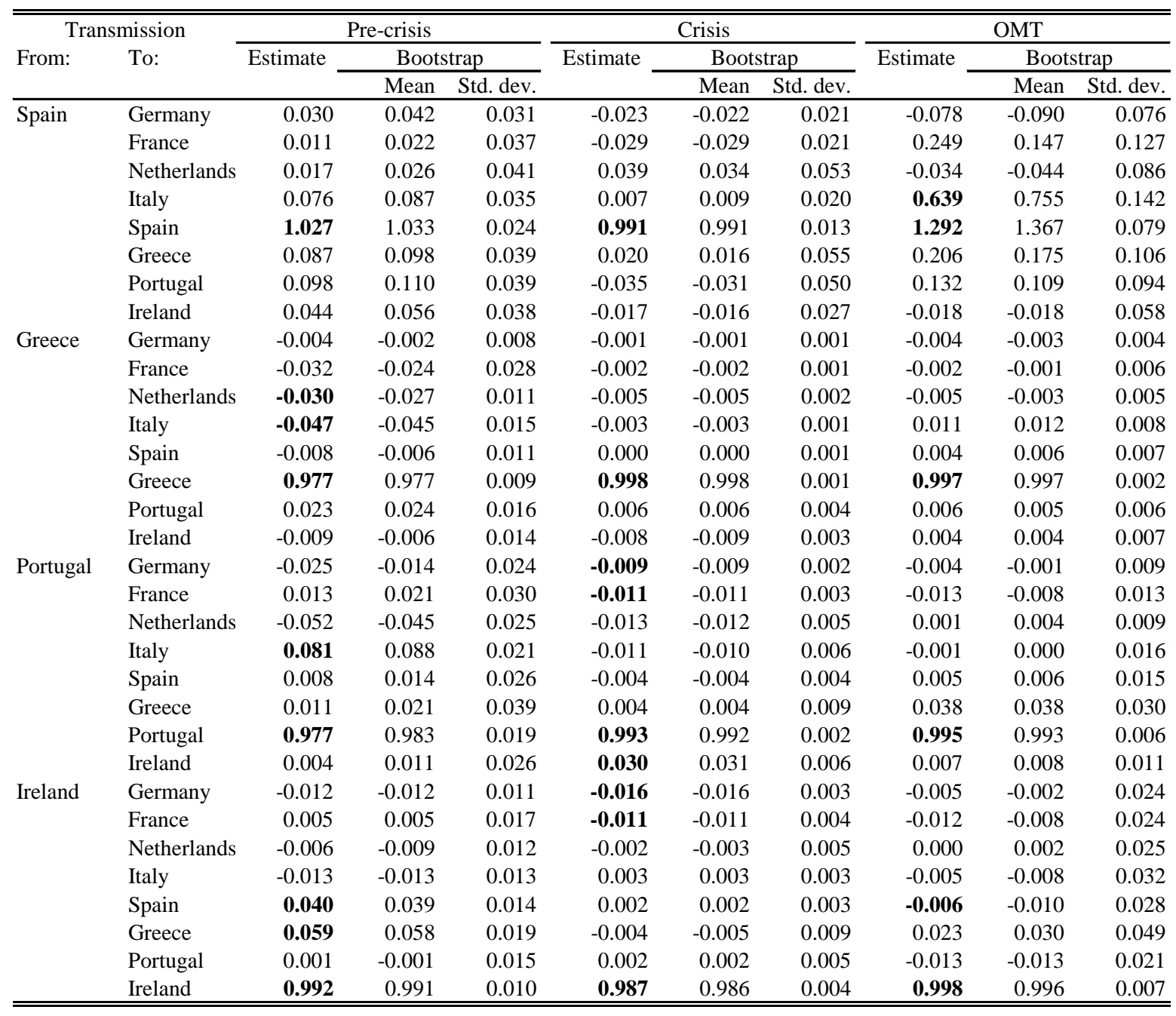

Notes: The table reports the parameter estimates of matrix $A^{-1}$ in model (2), obtained with the identification through heteroskedasticity using the statistical approach, along with the mean and standard deviation of 200 bootstrap replications. Bold numbers show coefficients that are statistically significant at the $1 \%$ level. The significance is judged through the p-value obtained in a bootstrap with 200 replications. 
Table A2: Parameter estimates and bootstrap results of structural-form model, statistical identification

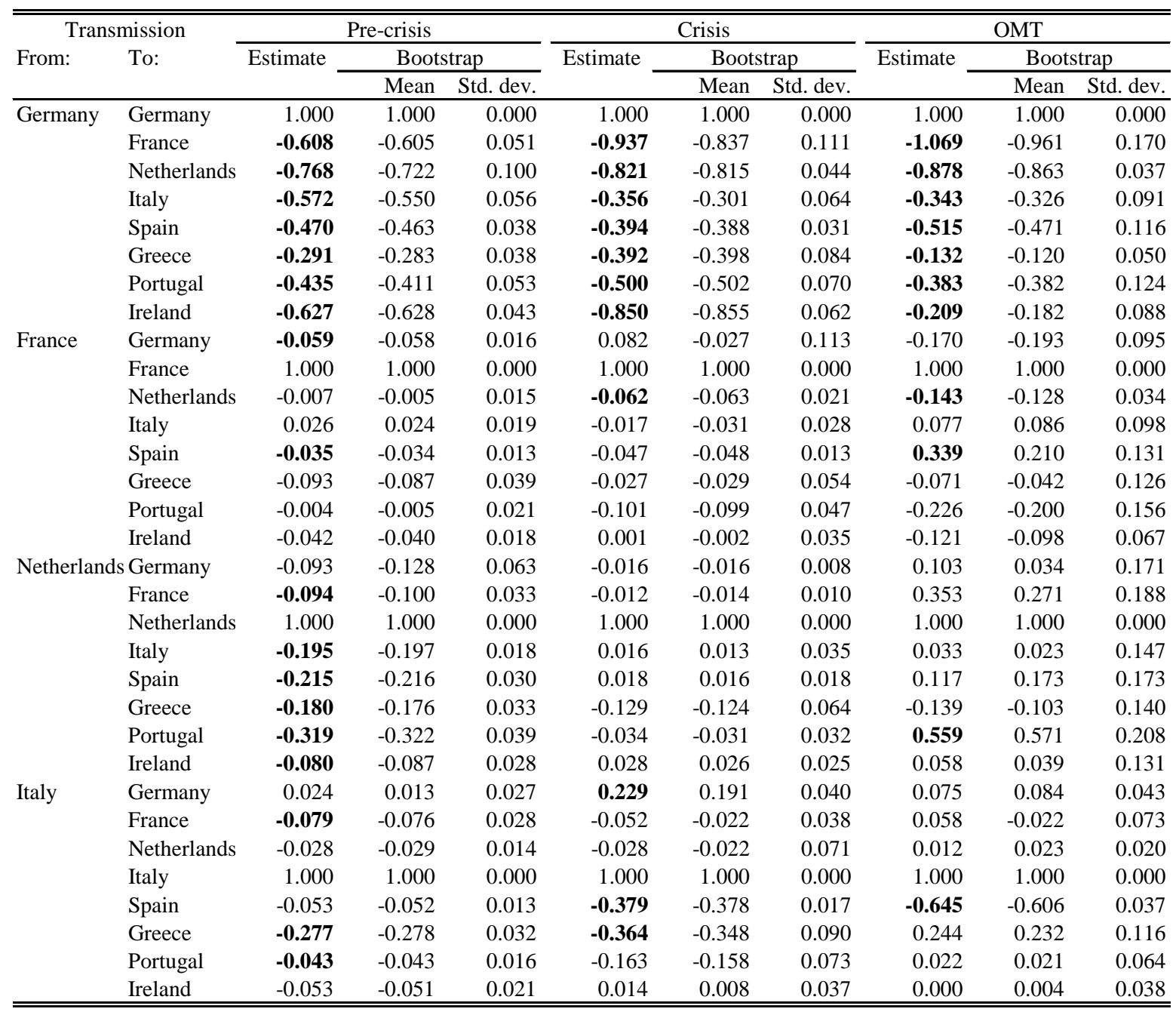

(continued) 
Table A2 (continued): Parameter estimates and bootstrap results of structural-form model, statistical identification

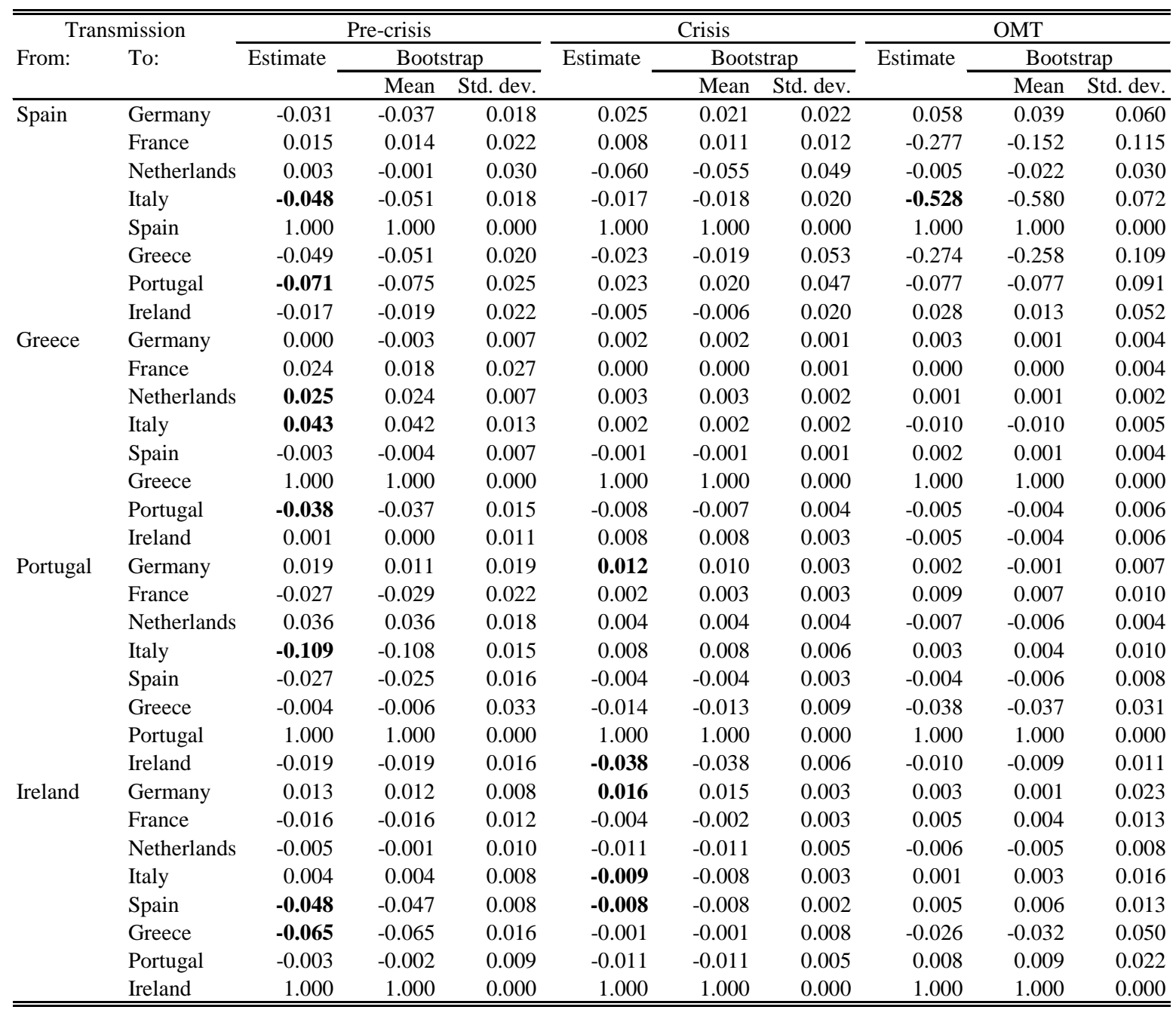

Notes: The table reports the parameter estimates of matrix $A$ in model (2), obtained with the identification through heteroskedasticity using the statistical approach, along with the mean and standard deviation of 200 bootstrap replications. Bold numbers show coefficients that are statistically significant at the $1 \%$ level. The significance is judged through the p-value obtained in a bootstrap with 200 replications. 
Table A3: Parameter estimates and bootstrap results of reduced-form model, narrative identification

\begin{tabular}{|c|c|c|c|c|c|c|c|c|c|c|}
\hline \multicolumn{2}{|c|}{ Transmission } & \multicolumn{3}{|c|}{ Pre-crisis } & \multicolumn{3}{|c|}{ Crisis } & \multicolumn{3}{|c|}{ OMT } \\
\hline \multirow[t]{2}{*}{ From: } & \multirow[t]{2}{*}{ To: } & \multirow[t]{2}{*}{ Estimate } & \multicolumn{2}{|c|}{ Bootstrap } & \multirow[t]{2}{*}{ Estimate } & \multicolumn{2}{|c|}{ Bootstrap } & \multirow[t]{2}{*}{ Estimate } & \multicolumn{2}{|c|}{ Bootstrap } \\
\hline & & & Mean & Std. dev. & & Mean & Std. dev. & & Mean & Std. dev. \\
\hline \multirow[t]{8}{*}{ Germany } & Germany & 1.132 & 1.133 & 0.017 & 1.078 & 1.126 & 0.104 & 1.466 & 1.564 & 0.617 \\
\hline & France & 0.883 & 0.883 & 0.018 & 0.691 & 0.727 & 0.172 & 1.132 & 1.210 & 0.471 \\
\hline & Netherlands & 0.785 & 0.776 & 0.055 & 0.908 & 0.976 & 0.148 & 1.268 & 1.371 & 0.648 \\
\hline & Italy & 0.678 & 0.670 & 0.055 & 0.431 & 0.410 & 0.084 & 0.687 & 0.582 & 0.724 \\
\hline & Spain & 0.703 & 0.694 & 0.046 & 0.506 & 0.494 & 0.150 & 0.289 & 0.189 & 0.676 \\
\hline & Greece & 0.873 & 0.871 & 0.023 & 0.350 & 0.368 & 0.328 & 0.402 & 0.514 & 0.753 \\
\hline & Portugal & 0.898 & 0.896 & 0.028 & 0.595 & 0.527 & 0.425 & 0.101 & 0.139 & 0.443 \\
\hline & Ireland & 0.934 & 0.935 & 0.023 & 0.608 & 0.692 & 0.341 & 0.683 & 0.700 & 0.176 \\
\hline \multirow[t]{8}{*}{ France } & Germany & 0.044 & 0.044 & 0.012 & 0.226 & 0.280 & 0.101 & 0.180 & 0.188 & 0.058 \\
\hline & France & 0.993 & 0.993 & 0.008 & 1.144 & 1.178 & 0.087 & 1.117 & 1.124 & 0.042 \\
\hline & Netherlands & 0.136 & 0.135 & 0.013 & 0.263 & 0.317 & 0.117 & 0.257 & 0.265 & 0.060 \\
\hline & Italy & 0.081 & 0.080 & 0.017 & 0.111 & 0.114 & 0.062 & 0.514 & 0.498 & 0.086 \\
\hline & Spain & 0.082 & 0.082 & 0.010 & 0.106 & 0.131 & 0.081 & 0.295 & 0.282 & 0.079 \\
\hline & Greece & 0.291 & 0.292 & 0.017 & 0.134 & 0.142 & 0.199 & -0.962 & -0.947 & 0.112 \\
\hline & Portugal & 0.065 & 0.066 & 0.015 & 0.164 & 0.165 & 0.262 & -0.085 & -0.077 & 0.093 \\
\hline & Ireland & -0.039 & -0.038 & 0.015 & 0.258 & 0.306 & 0.250 & 0.067 & 0.068 & 0.046 \\
\hline \multirow[t]{8}{*}{ Netherland } & s Germany & 0.155 & 0.163 & 0.049 & 0.005 & 0.007 & 0.009 & 0.617 & 0.697 & 0.508 \\
\hline & France & -0.082 & -0.072 & 0.060 & 0.005 & 0.006 & 0.012 & 0.429 & 0.495 & 0.394 \\
\hline & Netherlands & 1.093 & 1.096 & 0.019 & 1.003 & 1.003 & 0.009 & 1.453 & 1.534 & 0.507 \\
\hline & Italy & 0.436 & 0.438 & 0.016 & 0.004 & 0.005 & 0.007 & -1.366 & -1.431 & 0.532 \\
\hline & Spain & 0.462 & 0.464 & 0.021 & 0.007 & 0.007 & 0.009 & -1.187 & -1.258 & 0.520 \\
\hline & Greece & 0.029 & 0.041 & 0.063 & -0.029 & -0.028 & 0.032 & 1.331 & 1.411 & 0.613 \\
\hline & Portugal & 0.195 & 0.202 & 0.043 & 0.028 & 0.022 & 0.026 & -0.036 & -0.004 & 0.413 \\
\hline & Ireland & 0.127 & 0.134 & 0.046 & 0.094 & 0.086 & 0.065 & 0.734 & 0.748 & 0.178 \\
\hline \multirow[t]{8}{*}{ Italy } & Germany & 0.075 & 0.079 & 0.027 & -0.221 & -0.210 & 0.019 & -0.167 & -0.164 & 0.022 \\
\hline & France & 0.107 & 0.111 & 0.033 & -0.174 & -0.164 & 0.022 & -0.127 & -0.124 & 0.021 \\
\hline & Netherlands & 0.059 & 0.062 & 0.024 & -0.215 & -0.204 & 0.021 & -0.103 & -0.100 & 0.023 \\
\hline & Italy & 1.047 & 1.048 & 0.011 & 0.940 & 0.952 & 0.021 & 1.270 & 1.270 & 0.016 \\
\hline & Spain & 0.126 & 0.128 & 0.017 & 0.138 & 0.141 & 0.020 & 0.476 & 0.475 & 0.023 \\
\hline & Greece & 0.304 & 0.308 & 0.027 & -0.359 & -0.359 & 0.203 & -0.284 & -0.283 & 0.058 \\
\hline & Portugal & 0.053 & 0.057 & 0.031 & -0.006 & -0.008 & 0.096 & -0.072 & -0.069 & 0.025 \\
\hline & Ireland & 0.113 & 0.116 & 0.031 & -0.145 & -0.139 & 0.033 & -0.089 & -0.088 & 0.013 \\
\hline
\end{tabular}

(continued) 
Table A3 (continued): Parameter estimates and bootstrap results of reduced-form model, narrative identification

\begin{tabular}{|c|c|c|c|c|c|c|c|c|c|c|}
\hline \multicolumn{2}{|c|}{ Transmission } & \multicolumn{3}{|c|}{ Pre-crisis } & \multicolumn{3}{|c|}{ Crisis } & \multicolumn{3}{|c|}{ OMT } \\
\hline \multirow[t]{2}{*}{ From: } & \multirow[t]{2}{*}{ To: } & \multirow[t]{2}{*}{ Estimate } & \multicolumn{2}{|c|}{ Bootstrap } & \multirow[t]{2}{*}{ Estimate } & \multicolumn{2}{|c|}{ Bootstrap } & \multirow[t]{2}{*}{ Estimate } & \multicolumn{2}{|c|}{ Bootstrap } \\
\hline & & & Mean & Std. dev. & & Mean & Std. dev. & & Mean & Std. dev. \\
\hline \multirow{6}{*}{ Spain } & France & 0.114 & 0.115 & 0.018 & 0.028 & 0.041 & 0.031 & -0.099 & -0.094 & 0.035 \\
\hline & Netherlands & 0.108 & 0.110 & 0.013 & -0.006 & 0.020 & 0.046 & -0.034 & -0.028 & 0.037 \\
\hline & Italy & 0.161 & 0.163 & 0.010 & 0.141 & 0.161 & 0.035 & 0.909 & 0.906 & 0.017 \\
\hline & Greece & 0.306 & 0.309 & 0.019 & -0.018 & -0.012 & 0.157 & -0.441 & -0.436 & 0.056 \\
\hline & Portugal & 0.207 & 0.209 & 0.013 & 0.121 & 0.178 & 0.327 & -0.286 & -0.279 & 0.039 \\
\hline & Ireland & -0.051 & -0.047 & 0.035 & 0.006 & 0.034 & 0.086 & 0.041 & 0.042 & 0.017 \\
\hline \multirow[t]{5}{*}{ Greece } & Germany & -0.011 & -0.011 & 0.003 & -0.002 & -0.002 & 0.002 & -0.008 & -0.008 & 0.001 \\
\hline & France & -0.063 & -0.064 & 0.008 & -0.003 & -0.003 & 0.003 & 0.007 & 0.007 & 0.002 \\
\hline & Greece & 0.969 & 0.968 & 0.006 & 0.997 & 0.996 & 0.003 & 0.969 & 0.969 & 0.004 \\
\hline & Portugal & -0.015 & -0.015 & 0.011 & 0.005 & 0.005 & 0.010 & 0.010 & 0.010 & 0.002 \\
\hline & Ireland & 0.009 & 0.010 & 0.007 & -0.006 & -0.006 & 0.004 & -0.016 & -0.016 & 0.003 \\
\hline \multirow[t]{7}{*}{ Portugal } & Germany & -0.023 & -0.023 & 0.008 & -0.007 & -0.006 & 0.008 & -0.008 & -0.008 & 0.003 \\
\hline & France & -0.010 & -0.010 & 0.006 & -0.003 & -0.002 & 0.010 & 0.002 & 0.001 & 0.004 \\
\hline & Netherlands & 0.084 & 0.084 & 0.007 & -0.009 & -0.007 & 0.009 & -0.013 & -0.013 & 0.003 \\
\hline & Italy & 0.127 & 0.126 & 0.011 & -0.013 & -0.013 & 0.010 & 0.052 & 0.051 & 0.008 \\
\hline & Spain & 0.024 & 0.024 & 0.008 & -0.018 & -0.020 & 0.021 & 0.059 & 0.058 & 0.006 \\
\hline & Greece & 0.150 & 0.149 & 0.026 & 0.019 & 0.013 & 0.036 & 0.007 & 0.007 & 0.007 \\
\hline & Portugal & 0.982 & 0.982 & 0.008 & 0.994 & 0.984 & 0.023 & 0.990 & 0.990 & 0.004 \\
\hline \multirow{3}{*}{ Ireland } & Greece & 0.059 & 0.058 & 0.021 & 0.027 & 0.027 & 0.015 & 0.189 & 0.185 & 0.043 \\
\hline & Portugal & -0.046 & -0.046 & 0.014 & 0.015 & 0.015 & 0.013 & -0.019 & -0.016 & 0.017 \\
\hline & Ireland & 0.957 & 0.956 & 0.010 & 0.999 & 0.994 & 0.011 & 0.941 & 0.941 & 0.015 \\
\hline
\end{tabular}

Notes: The table reports the parameter estimates of matrix $A^{-1}$ in model (2), obtained with the identification through heteroskedasticity using the narrative approach, along with the mean and standard deviation of 200 bootstrap replications. Bold numbers show coefficients that are statistically significant at the $1 \%$ level. The significance is judged through the p-value obtained in a bootstrap with 200 replications. 
Table A4: Parameter estimates and bootstrap results of structural-form model, narrative identification

\begin{tabular}{|c|c|c|c|c|c|c|c|c|c|c|}
\hline \multicolumn{2}{|c|}{ "Transmission } & \multicolumn{3}{|c|}{ Pre-crisis } & \multicolumn{3}{|c|}{ Crisis } & \multicolumn{3}{|c|}{ Post-OMT } \\
\hline \multirow[t]{2}{*}{ From: } & \multirow[t]{2}{*}{ To: } & \multirow[t]{2}{*}{ Estimate } & \multicolumn{2}{|c|}{ Bootstrap } & \multirow[t]{2}{*}{ Estimate } & \multicolumn{2}{|c|}{ Bootstrap } & \multirow[t]{2}{*}{ Estimate } & \multicolumn{2}{|c|}{ Bootstrap } \\
\hline & & & Mean & $\overline{\text { Std. dev. }}$ & & Mean & Std. dev. & & Mean & Std. dev. \\
\hline \multirow[t]{8}{*}{ Germany } & Germany & 1.000 & 1.000 & 0.000 & 1.000 & 1.000 & 0.000 & 1.000 & 1.000 & 0.000 \\
\hline & France & -0.834 & -0.832 & 0.026 & -0.642 & -0.642 & 0.093 & -0.828 & -0.828 & 0.044 \\
\hline & Netherlands & -0.511 & -0.504 & 0.043 & -0.819 & -0.836 & 0.073 & -0.799 & -0.805 & 0.039 \\
\hline & Italy & -0.257 & -0.255 & 0.024 & -0.323 & -0.292 & 0.069 & -0.688 & -0.679 & 0.057 \\
\hline & Spain & -0.239 & -0.234 & 0.023 & -0.376 & -0.356 & 0.107 & -0.479 & -0.478 & 0.036 \\
\hline & Greece & -0.314 & -0.311 & 0.037 & -0.392 & -0.406 & 0.215 & -0.537 & -0.541 & 0.048 \\
\hline & Portugal & -0.737 & -0.735 & 0.039 & -0.418 & -0.374 & 0.188 & -0.387 & -0.381 & 0.042 \\
\hline & Ireland & -0.849 & -0.850 & 0.027 & -0.406 & -0.447 & 0.203 & -0.099 & -0.097 & 0.015 \\
\hline \multirow[t]{8}{*}{ France } & Germany & -0.023 & -0.022 & 0.010 & -0.214 & -0.247 & 0.059 & -0.126 & -0.124 & 0.013 \\
\hline & France & 1.000 & 1.000 & 0.000 & 1.000 & 1.000 & 0.000 & 1.000 & 1.000 & 0.000 \\
\hline & Netherlands & -0.102 & -0.101 & 0.008 & -0.075 & -0.075 & 0.048 & -0.083 & -0.083 & 0.005 \\
\hline & Italy & -0.020 & -0.019 & 0.011 & -0.019 & -0.011 & 0.046 & -0.330 & -0.327 & 0.019 \\
\hline & Spain & -0.027 & -0.027 & 0.007 & 0.006 & -0.001 & 0.036 & -0.176 & -0.176 & 0.034 \\
\hline & Greece & -0.264 & -0.264 & 0.015 & -0.065 & -0.054 & 0.131 & 0.967 & 0.965 & 0.050 \\
\hline & Portugal & -0.019 & -0.020 & 0.011 & -0.033 & -0.042 & 0.178 & 0.013 & 0.013 & 0.059 \\
\hline & Ireland & 0.081 & 0.081 & 0.012 & -0.124 & -0.120 & 0.169 & 0.079 & 0.077 & 0.045 \\
\hline \multirow[t]{8}{*}{ Netherlands } & s Germany & -0.086 & -0.091 & 0.032 & -0.005 & -0.006 & 0.008 & -0.332 & -0.344 & 0.064 \\
\hline & France & 0.247 & 0.243 & 0.024 & -0.001 & -0.002 & 0.009 & 0.074 & 0.071 & 0.060 \\
\hline & Netherlands & 1.000 & 1.000 & 0.000 & 1.000 & 1.000 & 0.000 & 1.000 & 1.000 & 0.000 \\
\hline & Italy & -0.317 & -0.315 & 0.014 & -0.002 & -0.002 & 0.005 & 0.757 & 0.753 & 0.048 \\
\hline & Spain & -0.351 & -0.352 & 0.012 & -0.004 & -0.002 & 0.006 & 0.683 & 0.692 & 0.090 \\
\hline & Greece & 0.191 & 0.186 & 0.032 & 0.034 & 0.033 & 0.031 & -0.532 & -0.533 & 0.040 \\
\hline & Portugal & -0.043 & -0.044 & 0.022 & -0.023 & -0.018 & 0.023 & 0.324 & 0.318 & 0.062 \\
\hline & Ireland & -0.018 & -0.018 & 0.018 & -0.090 & -0.081 & 0.065 & -0.510 & -0.506 & 0.074 \\
\hline \multirow[t]{8}{*}{ Italy } & Germany & -0.059 & -0.062 & 0.018 & 0.198 & 0.184 & 0.024 & 0.103 & 0.101 & 0.009 \\
\hline & France & -0.054 & -0.057 & 0.017 & 0.039 & 0.035 & 0.023 & -0.016 & -0.016 & 0.005 \\
\hline & Netherlanc & 0.004 & 0.001 & 0.015 & 0.023 & 0.020 & 0.018 & -0.022 & -0.022 & 0.005 \\
\hline & Italy & 1.000 & 1.000 & 0.000 & 1.000 & 1.000 & 0.000 & 1.000 & 1.000 & 0.000 \\
\hline & Spain & -0.073 & -0.073 & 0.008 & -0.238 & -0.230 & 0.033 & -0.402 & -0.401 & 0.013 \\
\hline & Greece & -0.219 & -0.220 & 0.018 & 0.283 & 0.285 & 0.206 & 0.072 & 0.072 & 0.055 \\
\hline & Portugal & 0.012 & 0.010 & 0.020 & -0.092 & -0.068 & 0.123 & -0.056 & -0.056 & 0.019 \\
\hline & Ireland & -0.066 & -0.065 & 0.016 & 0.017 & 0.012 & 0.059 & 0.056 & 0.056 & 0.009 \\
\hline
\end{tabular}


Table A4 (continued): Parameter estimates and bootstrap results of structural-form model, narrative identification

\begin{tabular}{|c|c|c|c|c|c|c|c|c|c|c|}
\hline \multicolumn{2}{|c|}{ Transmission } & \multicolumn{3}{|c|}{ Pre-crisis } & \multicolumn{3}{|c|}{ Crisis } & \multicolumn{3}{|c|}{ Post-OMT } \\
\hline \multirow[t]{2}{*}{ From: } & \multirow[t]{2}{*}{ To: } & \multirow[t]{2}{*}{ Estimate } & \multicolumn{2}{|c|}{ Bootstrap } & \multirow[t]{2}{*}{ Estimate } & \multicolumn{2}{|c|}{ Bootstrap } & \multirow[t]{2}{*}{ Estimate } & \multicolumn{2}{|c|}{ Bootstrap } \\
\hline & & & Mean & Std. dev. & & Mean & Std. dev. & & Mean & Std. dev. \\
\hline \multirow{6}{*}{ Spain } & France & -0.042 & -0.041 & 0.013 & -0.027 & -0.027 & 0.013 & 0.023 & 0.023 & 0.005 \\
\hline & Netherlands & -0.007 & -0.009 & 0.010 & 0.011 & 0.002 & 0.029 & -0.020 & -0.020 & 0.006 \\
\hline & Italy & -0.071 & -0.072 & 0.009 & -0.134 & -0.150 & 0.031 & -0.751 & -0.751 & 0.012 \\
\hline & Greece & -0.182 & -0.182 & 0.010 & -0.014 & -0.022 & 0.162 & 0.306 & 0.305 & 0.058 \\
\hline & Portugal & -0.103 & -0.102 & 0.010 & -0.101 & -0.155 & 0.334 & 0.233 & 0.230 & 0.037 \\
\hline & Ireland & 0.174 & 0.173 & 0.038 & 0.001 & -0.012 & 0.074 & -0.081 & -0.080 & 0.017 \\
\hline \multirow[t]{5}{*}{ Greece } & Germany & 0.008 & 0.007 & 0.003 & 0.000 & 0.000 & 0.002 & 0.004 & 0.004 & 0.000 \\
\hline & France & 0.053 & 0.053 & 0.007 & 0.002 & 0.002 & 0.002 & -0.014 & -0.014 & 0.001 \\
\hline & Greece & 1.000 & 1.000 & 0.000 & 1.000 & 1.000 & 0.000 & 1.000 & 1.000 & 0.000 \\
\hline & Portugal & 0.005 & 0.005 & 0.011 & -0.005 & -0.005 & 0.009 & -0.016 & -0.015 & 0.003 \\
\hline & Ireland & -0.014 & -0.015 & 0.007 & 0.004 & 0.005 & 0.003 & 0.012 & 0.012 & 0.002 \\
\hline \multirow[t]{7}{*}{ Portugal } & Germany & 0.037 & 0.037 & 0.007 & 0.009 & 0.007 & 0.006 & 0.000 & 0.000 & 0.001 \\
\hline & France & -0.021 & -0.020 & 0.007 & -0.002 & -0.002 & 0.005 & -0.008 & -0.008 & 0.002 \\
\hline & Netherlands & -0.095 & -0.094 & 0.007 & 0.003 & 0.003 & 0.004 & 0.009 & 0.009 & 0.001 \\
\hline & Italy & -0.110 & -0.109 & 0.010 & 0.009 & 0.008 & 0.007 & -0.003 & -0.003 & 0.003 \\
\hline & Spain & 0.018 & 0.018 & 0.006 & 0.012 & 0.016 & 0.019 & -0.033 & -0.033 & 0.004 \\
\hline & Greece & -0.143 & -0.142 & 0.028 & -0.017 & -0.012 & 0.037 & -0.043 & -0.043 & 0.007 \\
\hline & Portugal & 1.000 & 1.000 & 0.000 & 1.000 & 1.000 & 0.000 & 1.000 & 1.000 & 0.000 \\
\hline \multirow{2}{*}{ Ireland } & Portugal & 0.051 & 0.050 & 0.014 & -0.014 & -0.012 & 0.013 & 0.026 & 0.025 & 0.016 \\
\hline & Ireland & 1.000 & 1.000 & 0.000 & 1.000 & 1.000 & 0.000 & 1.000 & 1.000 & 0.000 \\
\hline
\end{tabular}

Notes: The table reports the parameter estimates of matrix $A$ in model (2), obtained with the identification through heteroskedasticity using the narrative approach, along with the mean and standard deviation of 200 bootstrap replications. Bold numbers show coefficients that are statistically significant at the $1 \%$ level. The significance is judged through the p-value obtained in a bootstrap with 200 replications. 